\title{
Tritium, Deuterium, and Oxygen-18 in Water Collected From Unsaturated Sediments Near a Low-Level Radioactive-Waste Burial Site South of Beatty, Nevada
}

By David E. Prudic, David A. Stonestrom, and Robert G. Striegl

\section{U.S. GEOLOGICAL SURVEY}

Water-Resources Investigations Report 97-4062

Prepared in cooperation with the IDAHO OPERATIONS OFFICE, SECRETARY OF ENERGY FOR ENVIRONMENTAL MANAGEMENT, U.S. DEPARTMENT OF ENERGY, under Interagency Agreement DE-AI07-94ID13282

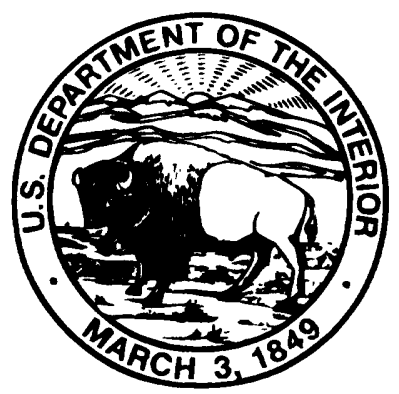

Carson City, Nevada 1997 


\title{
U.S. DEPARTMENT OF THE INTERIOR \\ BRUCE BABBITT, Secretary
}

\author{
U.S. GEOLOGICAL SURVEY \\ GORDON P. EATON, Director
}

Any use of trade names in this publication is for descriptive purposes

only and does not constitute endorsement by the U.S. Government

For additional information

write to:

District Chief

U.S. Geological Survey

333 West Nye Lane, Room 203

Carson City, NV 89706-0866

email: usgsinfo_nv@usgs.gov

http://wwwnv.wr.usgs.gov
Copies of this report can be purchased from:

U.S. Geological Survey

Branch of Information Services Box 25286

Denver, CO 80225-0286 


\section{CONTENTS}

Abstract

Introduction

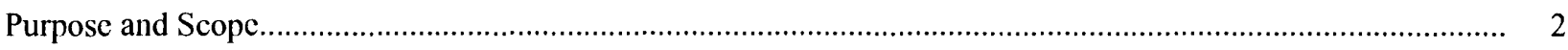

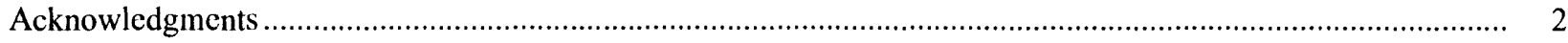

Test Holes.

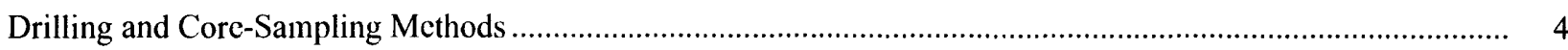

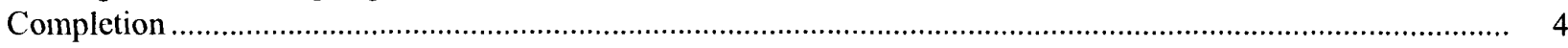

Water Collection Methods

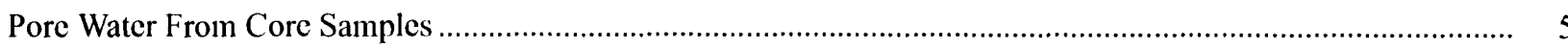

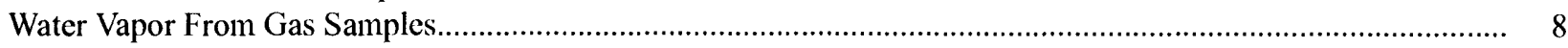

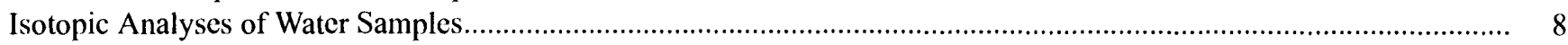

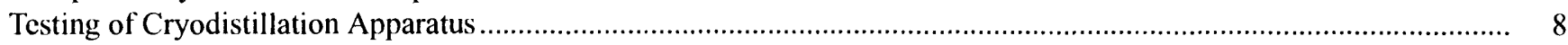

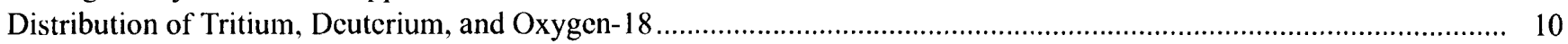

Comparison of Core Water to Ground Water and Precipitation ................................................................. 12

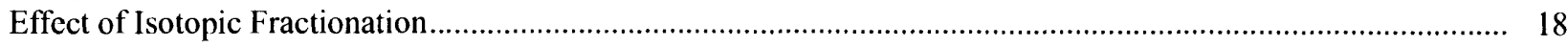

Possible Explanations for Observed Tritium Distributions .......................................................................... 18

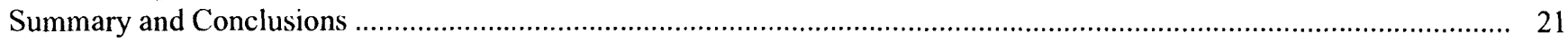

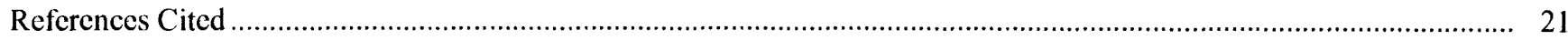

\section{FIGURES}

1. Map showing location of study and precipitation sites in Amargosa Desert and sampling sites near low-level radioactive-waste burial area south of Beatty, Nev.

2. Schematic of cryodistillation apparatus for extracting water from core samples............................................... 5

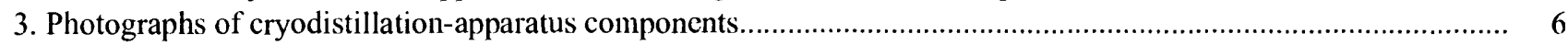

4. Photograph of cryodistillation apparatus extracting water from four core samples............................................ 7

5-9. Graphs showing:

5. Gravimetric water content of UZB-1 and UZB-2 core samples determined by oven drying in January 1993 and February 1994 and by cryodistillation in March $1996 .$.

6. Tritium concentration in water extracted from UZB-1 and UZB-2 core samples collected November 1992 and September 1993, and in water vapor from UZB-2 collected in April 1994, July 1995, and May 1996 ...

7. Distribution of deuterium and oxygen-18 in water extracted from UZB-1 and UZB-2 core samples that were collected in November 1992 and September 1993, respectively, and in water vapor sampled from UZB-2 air ports in April 1994, July 1995, and May 1996.

8. Relation between deutcrium and oxygen-18 for precipitation near Amargosa Valley, Nev., and ground water from wells and core water from UZB-1 and UZB-2

9. Concentrations of tritium in water vapor sampled from cight UZB-2 air ports in April 1994, July 1995, and May 1996, and concentrations in water vapor in November 1992 and September 1993, computed on the basis of water extracted from core samples

\section{TABLES}

1. Trap efficiency, residual water, and isotopic composition of water added to and removed from oven-dried sediments from test holes UZB-1 and UZB-2

2. Trap efficiency, residual water, and isotopic composition of pore water extracted from cores collected from test holes UZB-1 and UZB-2.

3. Tritium concentration in water vapor from unsaturated sediments, May 1996.

4. Deuterium and oxygen-18 composition of water vapor from unsaturated sediments, April 1994, July 1995, and May 1996

5. Tritium concentration and deuterium and oxygen- 18 composition of ground water from wells and test hole UZB-2, August 1989, December 1992, and September 1993 


\begin{tabular}{rll}
\hline Multiply & By & To obtain \\
\hline centimeter $(\mathrm{cm})$ & 0.3937 & inch \\
cubic $\operatorname{mcter}\left(\mathrm{m}^{3}\right)$ & 35.31 & cubic foot \\
cubic meter per cubic meter $\left(\mathrm{m}^{3} / \mathrm{m}^{3}\right)$ & 1 & cubic foot per cubic foot \\
gram $(\mathrm{g})$ & 0.03527 & ounce \\
gram per gram $(\mathrm{g} / \mathrm{g})$ & 1 & ounce per ounce \\
kilometer $(\mathrm{km})$ & 0.6215 & mile \\
kilogram $(\mathrm{kg})$ & 2.205 & pound \\
$\operatorname{liter}(\mathrm{L})$ & 1.057 & quart \\
pound per square inch \\
foot
\end{tabular}

Temperature: Degrees Celsius $\left({ }^{\circ} \mathrm{C}\right)$ can be converted to degrees Fahrenheit $\left({ }^{\circ} \mathrm{F}\right)$ by using the formula ${ }^{\circ} \mathrm{F}=\left[1.8\left({ }^{\circ} \mathrm{C}\right)\right]+32$. Degrees Fahrenheit can be converted to degrees Celsius by using the formula ${ }^{\circ} \mathrm{C}=\left({ }^{\circ} \mathrm{F}-32\right) / 1.8$.

Chemical concentration: Tritium units (TU) can be converted to picocuries per liter ( $\mathrm{pCi} / \mathrm{L}$ ) by multiplying tritium units by 3.2 (Fritz and Fontes, 1980, p. 14). Deuterium (D) and oxygen-18 $\left({ }^{18} \mathrm{O}\right)$ are reported using delta $(\delta)$ notation in units of parts per thousand (permil). Delta notation represents the relative difference between the ratios of $\mathrm{D}$ to hydrogen-1 $\left({ }^{1} \mathrm{H}\right)$ or ${ }^{18} \mathrm{O}$ to oxygen-16 $\left({ }^{16} \mathrm{O}\right)$ in a sample and a standard water (Friedman and O’Neil, 1977). Vienna Standard Mean Ocean Water (VSMOW) was used as the standard water.

Sea level: In this report, "sea level" refers to the National Geodetic Vertical Datum of 1929 (NGVD of 1929, formerly callcd "Sea-Level Datum of 1929"), which is derived from a general adjustment of the first-order leveling networks of the United States and Canada. 


\title{
Tritium, Deuterium, and Oxygen-18 in Water Collected From Unsaturated Sediments Near a Low-Level Radioactive-Waste Burial Area South of Beatty, Nevada
}

\author{
by David E. Prudic, David A. Stonestrom, and Robert G. Striegl
}

\section{Abstract}

Pore water was extracted in March 1996 from core samples collected from test holes UZB1 and UZB-2 drilled November 1992 and September 1993, respectively, in the Amargosa Desert south of Beatty, Nevada. The test holes are part of a study to determine factors affecting water and gas movement through unsaturated sediments. The holes are about 100 meters south of the southwest corner of the fence enclosing a commercial burial area for low-level radioactive waste. Water vapor collected from test hole UZB-2 in April 1994 and July 1995 had tritium concentrations greater than would be expected from atmospheric deposition. An apparatus was built in which pore water was extracted by cryodistillation from the previously obtained core samples. The extracted core water was analyzed for the radioactive isotope tritium and for the stable isotopes deuterium (D) and oxygen-18 $\left({ }^{18} \mathrm{O}\right)$. The isotopic composition of core water was compared with that of water vapor previously collected from air ports in test hole UZB-2 and to additional samples collected during May 1996.

Core water becomes increasingly depleted in $\mathrm{D}$ and ${ }^{18} \mathrm{O}$ from the land surface to a depth of 30 meters, indicating that net evaporation of water is occurring near the land surface. Below a depth of 30 meters the stable-isotopic composition of core water becomes nearly constant and roughly equal to that of ground water. The stable isotopes plot on an evaporation trend. The source of the partly evaporated water could be either ground water or past precipitation having the same average isotopic composition as ground water but not modern precipitation, based on 18 months of record.
Profiles of $\mathrm{D}$ and ${ }^{18} \mathrm{O}$ in water vapor roughly parallel those in core water. The stable isotopes of core water appear to be in isotopic equilibrium with water vapor from UZB-2 when temperaturedependent fractionation is considered. The data are consistent with the hypothesis of evaporative discharge of ground water at the land surface.

The concentration of tritium in core water from depths less than 50 meters was higher than that of present-day atmospheric air, indicating that elevated tritium concentrations preceded drilling. The concentrations of tritium in core water from the deepest sample ( 85 meters) and in UZB-2 ground water (110 meters) were below detection. Thus, tritium in the unsaturated zone is not being introduced through ground water.

The shape of the tritium profile for core water was similar to the shape of the tritium profile for water vapor collected April 1994, except that concentrations were consistently lower in core water than in water vapor. Tritium concentrations in water vapor increased from April 1994 to May 1996. Similar to the stable isotopes, the highest tritium concentrations were measured at shallow depths. Concentrations of tritium in water vapor during core collection were estimated assuming isotopic equilibrium with core water. The computed concentrations for November 1992 and September 1993 form consistent temporal trends with subsequent tritium concentrations in water vapor collected April 1994, July 1995, and May 1996. Observations of a bimodal distribution of tritium, in which the highest concentrations are in a gravel layer at a depth of 1-2 meters, indicate lateral migration of tritium through the vicinity of UZB-2. 


\section{INTRODUCTION}

In November 1992, test hole UZB-1 was drilled to a depth of $48 \mathrm{~m}$ by the U.S. Geological Survey 101 $m$ south of the southwest corner of a commercial burial area for low-level radioactive waste (fig. 1). The burial area is in the Amargosa Desert about $17 \mathrm{~km}$ south of Beatty, Nev. Burial of low-level radioactive waste began in September 1962 and continued through 1992 when the burial area was closed. Precipitation at the site averages about $100 \mathrm{~mm} / \mathrm{yr}$ (Andraski and others, 1995). Depth to ground water near the test hole is about $110 \mathrm{~m}$ below land surface. The hole was drilled to test a new design for installing thermocouple psychrometers that allows for their removal and replacement. Thermocouple psychrometers are used to measure water potential and temperature in the unsaturated sediments at the site.

In September 1993, test hole UZB-2 was drilled to a depth of $114.6 \mathrm{~m}$ by the U.S. Geological Survey about $6 \mathrm{~m}$ northeast of UZB-1. This test hole was drilled to monitor changes in subsurface gas pressures in relation to atmospheric pressure and to determine the natural distribution of gases for estimating the depth of atmospheric air circulation in the unsaturated sediments (Prudic, 1996).

Core samples were collected at selected depths from both test holes. Sections of the core were analyzed for particle size, bulk density, porosity, water content, water potential, and chloride concentration. Bulk densities, water contents, and chloride concentrations are reported by Prudic (1994). Water potentials are reported by Andraski and Prudic (1997). Both test holes are part of a study to determine the factors affecting water and gas movement through unsaturated sediments at the desert site.

Gas was pumped from test hole UZB-2 in April 1994 and July 1995. Water vapor and carbon dioxide were extracted from the pumped gas. The water vapor was analyzed for the radioactive isotope tritium and the stable isotopes deuterium (D) and oxygen-18 $\left({ }^{18} \mathrm{O}\right)$. Carbon dioxide was analyzed for the stable isotope carbon- $13\left({ }^{13} \mathrm{C}\right)$ and the radioactive isotope carbon- 14 $\left({ }^{14} \mathrm{C}\right)$. Tritium and ${ }^{14} \mathrm{C}$ analyses of the gas samples are reported by Prudic and Striegl (1995). Interpretation of the distribution of tritium and ${ }^{14} \mathrm{C}$ found in UZB-2 is summarized by Striegl and others (1996). Because tritium concentrations in UZB-2 gas samples were greater than expected, a method was developed in early 1996 to extract water from archived sections of cores.
Extracted core water was analyzed for tritium, D, and ${ }^{18} \mathrm{O}$. In addition, water vapor was collected again from UZB-2 in May 1996 and analyzed for tritium, D, and ${ }^{18} \mathrm{O}$. Laboratory results for tritium in core water and water vapor were received in April 1996 and June 1996 , respectively. Laboratory results for ${ }^{18} \mathrm{O}$ were received in April 1996 and October 1996, and results for $\mathrm{D}$ for both sets of samples were received in October 1996. Laboratory results for $\mathrm{D}$ and ${ }^{18} \mathrm{O}$ for one vapor sample and five water samples used in testing the cryodistillation apparatus were received in November 1996 and January 1997.

\section{Purpose and Scope}

The purposes of this report are (1) to describe the methods used to drill test holes, collect core samples, and extract pore water from the core samples, (2) to compare the distributions of tritium, $\mathrm{D}$, and ${ }^{18} \mathrm{O}$ in core water with those of water vapor sampled from air ports in test hole UZB-2, and (3) to give a preliminary interpretation of the observed distributions.

\section{Acknowledgments}

Many people contributed to the work described in this report. Kathryn C. Kilroy, Mary L. Tumbusch, James L. Wood, and Armando R. Robeldo (U.S. Geological Survey, Carson City, Nev.) assisted during the drilling, coring, and completion of test holes UZB-1 and UZB-2. Alan C. Riggs (U.S. Geological Survey, Lakewood, Colo.) collected water vapor from the unsaturated sediments in May 1996. Robert L. Michel (U.S. Geological Survey, Menlo Park, Calif.) analyzed tritium concentration in core water and in water vapor from unsaturated sediments. Jessica A. Hopple (U.S. Geological Survey, Reston, Va.) analyzed D and ${ }^{18} \mathrm{O}$ in water vapor collected in April 1994. Lloyd D. White (U.S. Geological Survey, Menlo Park, Calif.) analyzed $\mathrm{D}$ and ${ }^{18} \mathrm{O}$ in core water and in water vapor collected in July 1995 and May 1996.

Funding for the tritium analyses of water from core samples was provided by the Idaho Operations Office, Secretary of Energy for Environmental Management, U.S. Department of Energy, under Interagency Agreement DE-AI07-94ID13282. 

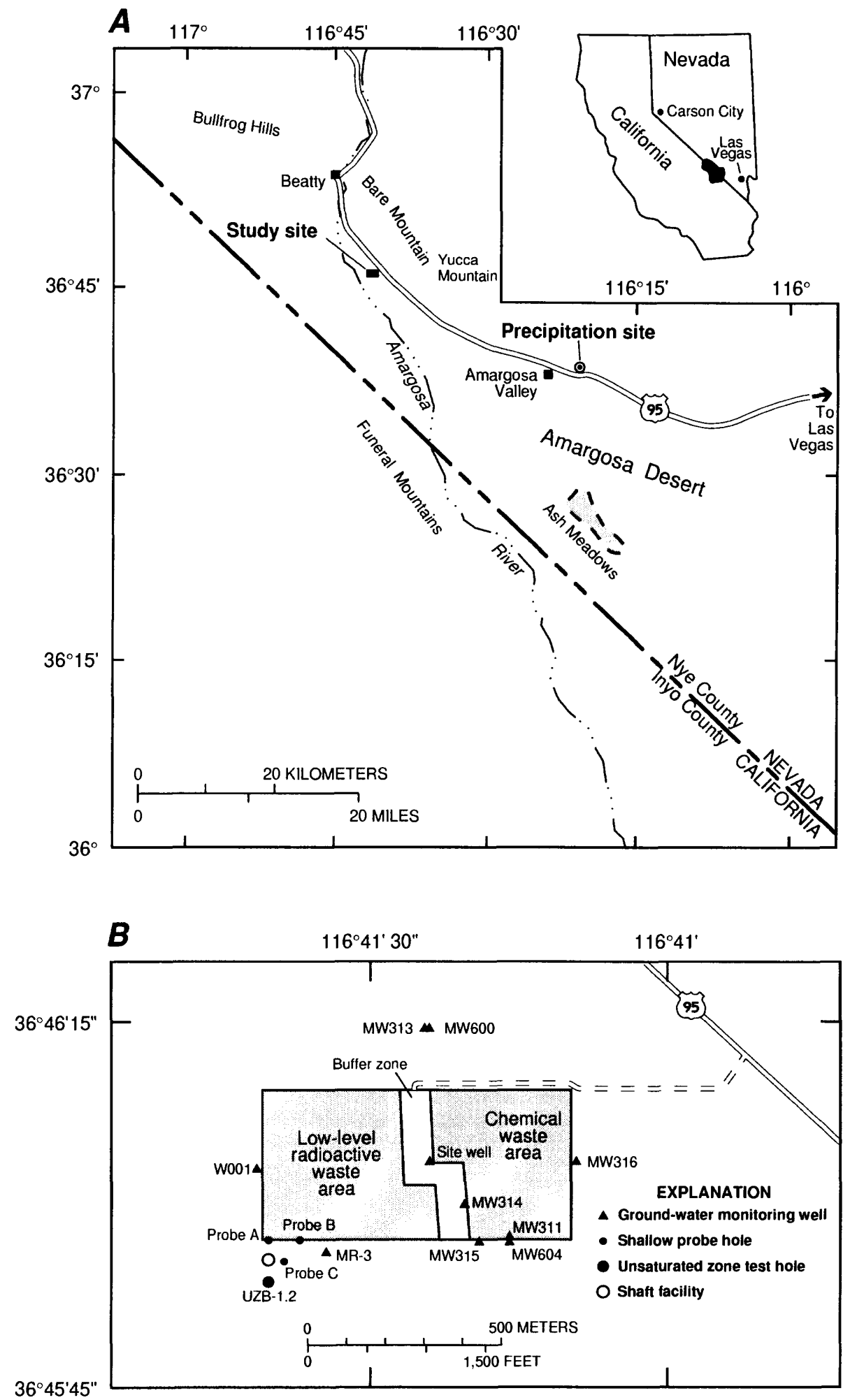

Figure 1. Location of $(A)$ study and precipitation sites in Amargosa Desert, and $(B)$ sampling sites near low-level radioactive-waste burial area south of Beatty, Nev. 


\section{TEST HOLES}

\section{Drilling and Core-Sampling Methods}

Test holes UZB-1 and UZB-2 were drilled using the ODEX air-hammer drilling method (Hammermeister and others, 1985). Each hole was drilled using a 20-cm diameter eccentric bit attached to a down-hole hammer. Threaded casing having an outside diameter of $17 \mathrm{~cm}$ was attached to the bit with a special shoe connected to the casing. Additional casing was inserted as the hole was drilled deeper. For UZB-1, 3-m long sections of casing were used. For UZB-2, 3- and 6-m long sections were used. Air injected down the drill stem carried cuttings to the surface through the inside of the casing. At the surface, a hose discharged the cuttings and air into a cyclone separator where coarse cuttings dropped out and fine particles discharged to the air. At each depth where a core was collected, the bit and hammer were removed through the casing after reversing the normal rotation of the drill stem.

Test hole UZB-1 was drilled to a depth of $48 \mathrm{~m}$ and was dry. An initial hole was drilled to a depth of $24 \mathrm{~m}$ where the core sampler broke off and could not be retrieved. The hole was backfilled with a mixture of cuttings and bentonite and a second hole was drilled to a depth of $48 \mathrm{~m}$ about $2 \mathrm{~m}$ to the west. Because of their close proximity, both are referred to as UZB-1. Test hole UZB-2 was drilled to a depth of $114.6 \mathrm{~m}$, about $5 \mathrm{~m}$ below the water table. UZB-2 is about $6 \mathrm{~m}$ northeast of the second UZB-1 hole. In UZB-2, casing was advanced to a depth of $91 \mathrm{~m}$ using the ODEX method. Below a depth of $91 \mathrm{~m}, \mathrm{UZB}-2$ was drilled using a rotary method with a tricone bit after the casing broke at a depth of $61 \mathrm{~m}$ and could not be advanced further. As in the ODEX method, air was used to remove cuttings. The hole was uncased below $91 \mathrm{~m}$.

A solid tube sampler of hardened steel with an inside diameter of about $10 \mathrm{~cm}$ was used to collect core samples in brass liners with individual segment lengths of 7.5 and $15 \mathrm{~cm}$. The sampler was driven into sediments at the bottom of the hole with an air hammer. Approximately $60 \mathrm{~cm}$ of core were collected with the sampler at each sampling depth. Core recovery was nearly 100 percent. Brass liners were removed from the sampler using a pneumatic ram that pushed the liners out of the sampler. The liners were immediately capped, taped, and labeled in the field. Samples collected from UZB-1 were sealed in ProtecCore tubular laminate. Samples collected from UZB-2 were capped, taped, then sealed in paraffin. The sample in the uppermost $7.5-\mathrm{cm}$ brass liner of each core contained cuttings from the drill bit and was discarded.

Seven cores were collected from UZB- 1 about every $3 \mathrm{~m}$ starting at $2.3 \mathrm{~m}$ below land surface. No samples were collected below $21.2 \mathrm{~m}$ because the solid tube sampler broke off from the down-hole air hammer at a depth of $24.4 \mathrm{~m}$. No core samples were collected from the second UZB-1 hole. A new solidtube sampler, with a greater wall thickness, was used for test hole UZB-2. Cores were collected from UZB2 at 26.7 to $27.3 \mathrm{~m}, 35.9$ to $36.5 \mathrm{~m}, 48.0$ to $48.6 \mathrm{~m}$, 60.2 to $60.8 \mathrm{~m}, 72.5$ to $73.1 \mathrm{~m}$, and 84.7 to $85.3 \mathrm{~m}$ below land surface. With two exceptions, the deepest $15-\mathrm{cm}$ segment of each core was used for water extraction to minimize impacts from drilling. No core was analyzed from the interval 26.7 to $27.3 \mathrm{~m}$ because lubricating oil from the air hammer had coated the outside of the core barrel. Two $7.5-\mathrm{cm}$ segments from the upper part of the 72.5 to $73.1-\mathrm{m}$ core were combined because deeper cores had been used for other analyses.

\section{Completion}

Test hole UZB-1 was completed with four 3.2cm PVC pipes fitted with specially designed end caps for installation of thermocouple psychrometers. The pipes were installed at depths of $47.9 \mathrm{~m}, 34.1 \mathrm{~m}, 14.9$ $\mathrm{m}$, and $5.2 \mathrm{~m}$ below land surface as the casing was removed and the hole was backfilled. Fine to medium gravel ranging from 1.3 to $4.8 \mathrm{~mm}$ in diameter was placed from about $30 \mathrm{~cm}$ below to $60 \mathrm{~cm}$ above the end caps of each pipe. Intervals between fine-gravel layers were filled with a mixture of medium to coarse sand ( 0.4 to $1 \mathrm{~mm}$ in diameter), silica flour, and powdered bentonite, and thin layers of dry bentonite. Except for the dry bentonite, small quantities of Beatty tap water were added to the backfill mixture to produce a water content of about 10 percent by volume (the approximate water content of the undisturbed sediments). Although Beatty tap water was not analyzed for tritium in November 1992, water from one of the supply wells reported by Black and others (1994, p. D-25) was below the two standarddeviation detection limit in January 1993 ( $\pm 88 \mathrm{TU}$ ) and July 1993 ( $\pm 1.0 \mathrm{TU})$.

Ten air ports were installed in UZB-2 (Prudic and Striegl, 1995). Each air port consisted of a $30-\mathrm{cm}$-long stainless steel screen connected to 
6-mm diameter nylon tubing that extended to land surface. Each screen was embedded in a $60-\mathrm{cm}$ interval of fine to medium gravel. A mixture of sand, silica flour, and powdered bentonite was placed above and below each gravel layer. Bentonite grout was pumped into the hole above the mixture of sand, silica flour, and powdered bentonite to seal the hole between screens. The uppermost $2.1 \mathrm{~m}$ was filled with cement grout. Water used for the bentonite and cement grouts was obtained from the site well (location shown in fig. $1 B$ ). This well was sampled in August 1989 by the U.S. Geological Survey (table 5) at which time the tritium concentration was less than 0.6 TU. The well was sampled on September 16, 1993 (the day after UZB-2 was completed), at which time the tritium concentration was $0.5 \pm 2.2 \mathrm{TU}$ (Black and others, 1994, p. D-25). Additionally, the well is sampled quarterly by the site operator. Reported concentrations for samples collected in June, August, and October 1993 were less than the detection limit of 94 TU (Douglas Greffin, US Ecology, Inc., written commun., 1996).

\section{WATER COLLECTION METHODS}

\section{Pore Water From Core Samples}

Archived core samples, sealed in moisture-tight packaging described in the preceding section, were stored in a laboratory cabinet between the time of collection and the time of analysis. The extracted core water was analyzed for tritium, $\mathrm{D}$, and ${ }^{18} \mathrm{O}$.

An apparatus (fig. 2) was constructed to extract water directly from sediments in the brass core liners by cryodistillation. The brass core liners were sealed into brass end caps with o-rings. The caps were held in place by bolts (fig. $3 A$ ). A heating tape, wrapped around the core liner, was surrounded by thermal insulation (fig. $3 B$ ). A thermocouple probe at the center of the bottom end cap penetrated a few millimeters into the lower face of the core sample, measuring internal temperature at that point. An external thermocouple beneath the heating tape measured temperature at a point on the outside of the core liner. A ground glass

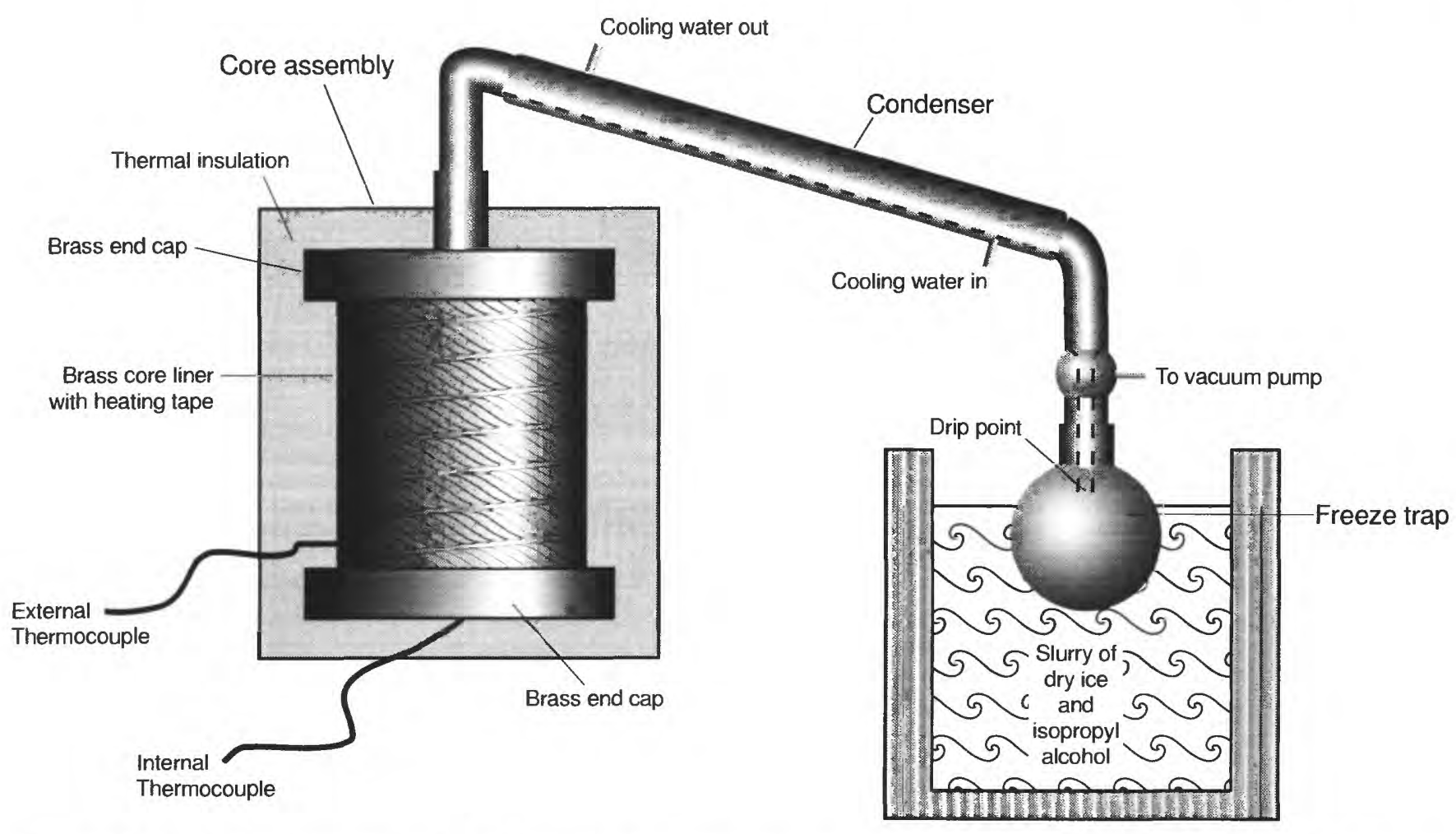

Figure 2. Cryodistillation apparatus for extracting water from core samples collected from test holes UZB-1 and UZB-2 near low-level radioactive-waste burial site south of Beatty, Nev. Diagram not drawn to scale. Core liner is 15 centimeters long and 10 centimeters in diameter. Brass end caps are 15 centimeters in diameter. Vertical distance between outside surfaces of end caps is 17.6 centimeters. Freeze trap is 250 milliliter flask. Distance between cooling water ports on condenser is 25.5 centimeters. 
A.

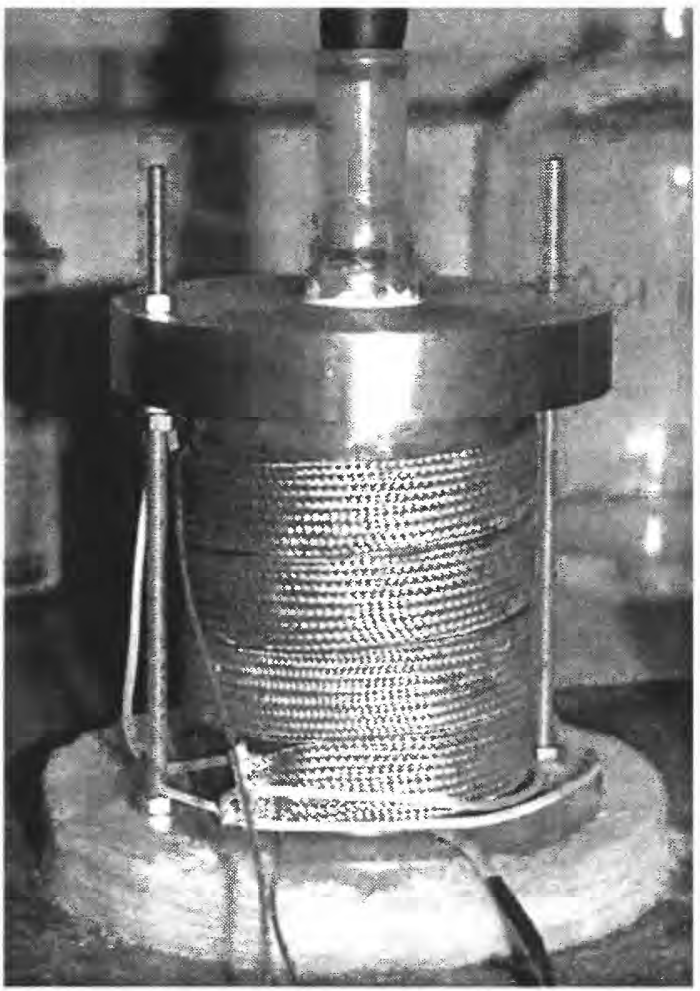

B.

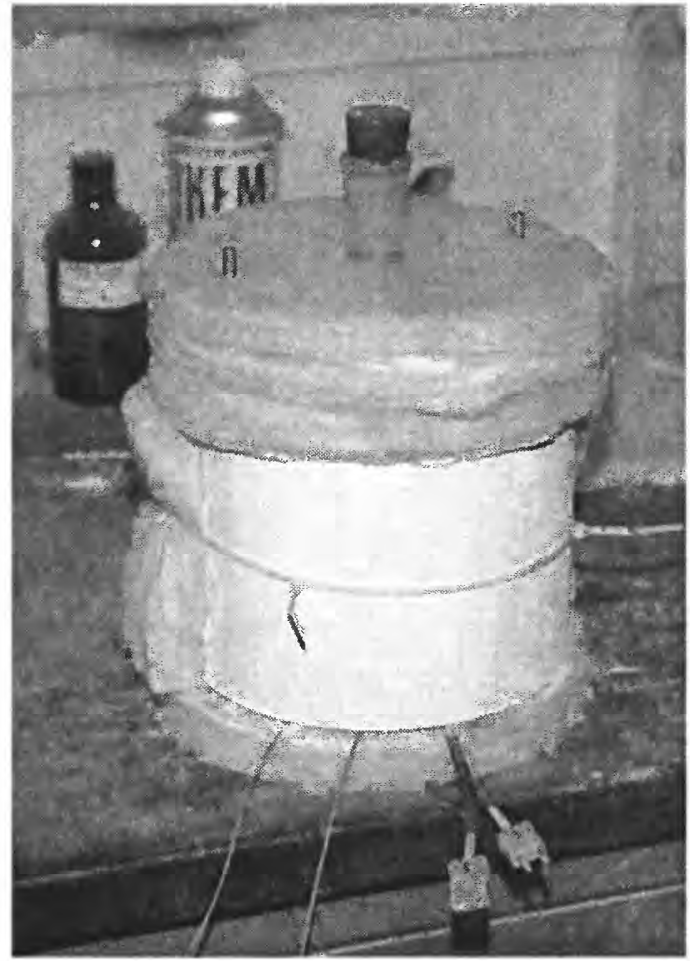

c.

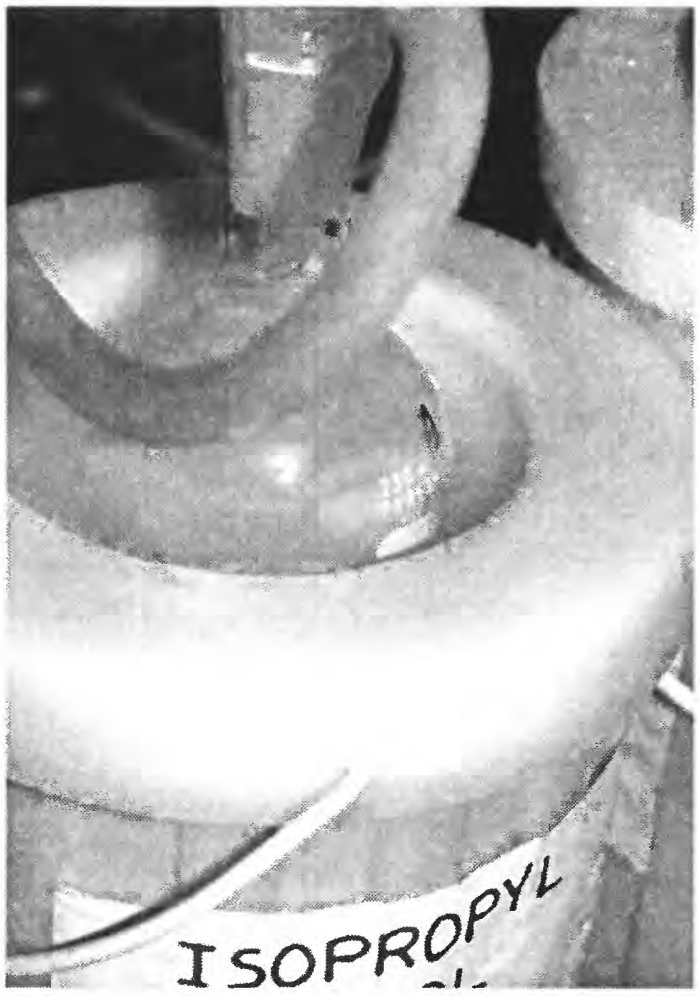

Figure 3. Cryodistillation-apparatus components: $(A)$ brass end caps, heating tape, and external thermocouple wire attached to 15-centimeter long, 10-centimeter diameter brass core liner; $(B)$ thermal insulation surrounding brass core liner and end caps; and $(C)$ freeze trap consisting of 250-milliliter collection flask immersed in a slurry of dry ice and isopropyl alcohol. 
fitting in the upper brass end cap connected the core assembly to a condenser. Circulating tap water cooled the condenser. The condenser connected to a freeze trap, which consisted of a drip point inserted into a $250-\mathrm{mL}$ collection flask. The flask was cooled by a slurry of dry-ice shavings in isopropyl alcohol (fig. $3 C$ ). A vacuum pump removed air from the apparatus, facilitating the transfer of vapor from the core sample to the freeze trap.

The core samples were removed from their moisture-tight packaging and quickly fitted with brass end caps to minimize evaporation and isotopic exchange with atmospheric moisture. After the heater tape and insulation were secured around the liner and caps, the core assembly was installed on the condenser and a dry-ice slurry was placed around the collection flask. Four core assemblies were attached to individual condensers and freeze traps (fig. 4). These were connected in turn to a single, ballasted, vacuum pump. After the four flasks had cooled several minutes, a valve between each freeze trap and vacuum line was slowly opened. After the system reached an absolute pressure of about $500 \mathrm{~Pa}$, the heater control system was activated.
The heater control system applied heat to each core sample when the external temperature was below $110^{\circ} \mathrm{C}$ and the internal temperature was below $105^{\circ} \mathrm{C}$. Water extraction ended when the internal temperatures of the core samples became nearly constant at about $100^{\circ} \mathrm{C}$. This usually required $4-5$ hours of heating.

Following water extraction, each core assembly and collection flask were removed from their condenser and dry-ice slurry, respectively. Rubber stoppers were inserted into the glass mouth of each core assembly and collection flask. The sealed flask was immediately placed under running water to melt accumulated ice and prevent the flask from breaking due to differential expansion of glass and ice. The outside of the flask was dried and the flask with stopper and accumulated ice weighed. After all ice had melted, a $14 \mathrm{~mL}$ aliquot of water was transferred by pipette from the flask to a glass bottle for analysis of $\mathrm{D}$ and ${ }^{18} \mathrm{O}$. The remaining water was transferred into $50-\mathrm{mL}$ glass bottles for tritium analysis. The core assembly was disassembled and the sediments quickly removed from the brass liner. Sediments were weighed then dried overnight at about $104^{\circ} \mathrm{C}$ in a forced-convection oven for determination of water remaining in the sediments.

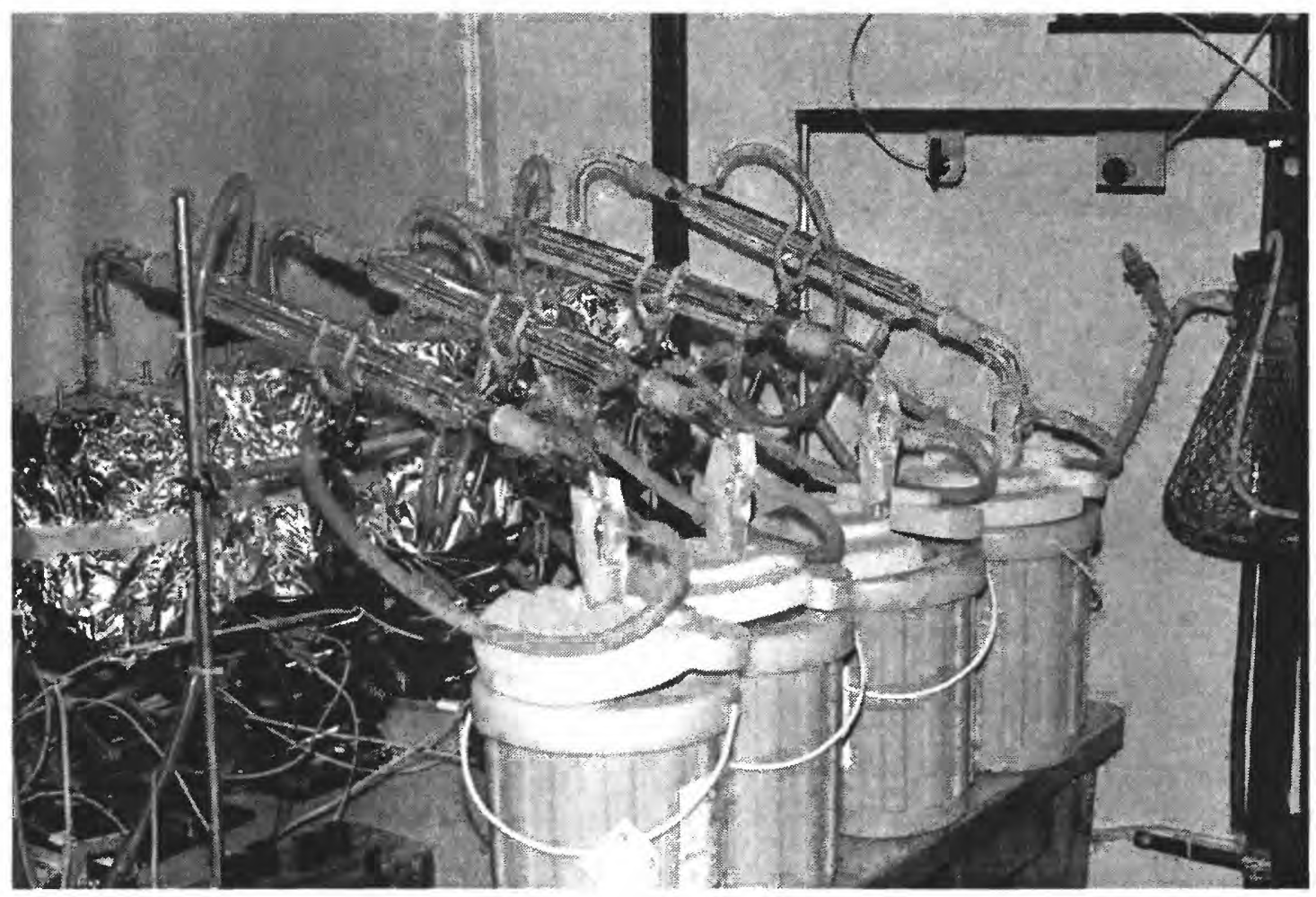

Figure 4. Cryodistillation apparatus extracting water from four core samples. 


\section{Water Vapor From Gas Samples}

Water vapor was extracted from gas pumped from air ports in UZB-2 in April 1994 and July 1995 (Prudic and Striegl, 1995) and again in May 1996. Prior to initial sampling in April 1994, gas was pumped from each air port on four separate occasions. A total volume of about $100 \mathrm{~L}$ of gas was pumped from each port (Prudic and Striegl, 1995). This gas was analyzed for carbon dioxide. By April 1994, carbon-dioxide concentrations had become reasonably stable, indicating that most air injected during drilling had been removed.

Water vapor was collected by pumping gas at a low rate (less than $10 \mathrm{~mL} / \mathrm{s}$ ) through a freeze trap immersed in a slurry of methyl alcohol and dry ice (Striegl, 1988). Condensed water vapor was collected as ice in the trap. Upon collection of a sufficient volume of water, the ice was allowed to thaw and the resulting liquid was poured into glass vials and sealed. About $10 \mathrm{~mL}$ of liquid water was collected every 24 hours. In July 1995, water vapor also was extracted from gas pumped from two hardened-steel probes driven into the ground along the security fence (probes $\mathrm{A}$ and $\mathrm{B}$, fig. $1 B$ ). The probes were installed at depths of about $1.7 \mathrm{~m}$ below land surface. In May 1996, water vapor was extracted from probe $\mathrm{B}$, from a shallow probe driven to depth of $1.68 \mathrm{~m}$ less than $1 \mathrm{~m}$ from UZB-2, and from a probe driven to a depth of $2.0 \mathrm{~m}$ about midway between UZB-2 and probe B (probe C in fig. $1 B$ ).

\section{ISOTOPIC ANALYSES OF WATER SAMPLES}

All isotope analyses of core water and water vapor were done at U.S. Geological Survey, Water Resources Division laboratories in Menlo Park, Calif., and Reston, Va. Tritium was analyzed using the method described by Thatcher and others (1977). Deuterium was analyzed using the method described by Kendall and Coplen (1985). Oxygen-18 was analyzed using the method described by Epstein and Mayeda (1953). Tritium concentration is reported in tritium units (TU) where 1 TU is equal to 1 tritium atom per $10^{18}$ hydrogen atoms (Evans, 1966). Deuterium and ${ }^{18} \mathrm{O}$ are reported in delta $(\delta)$ notation as parts per thousand (permil). Delta is the relative difference between the ratios of $\mathrm{D}$ to hydrogen- $1\left({ }^{1} \mathrm{H}\right)$, or ${ }^{18} \mathrm{O}$ to oxygen-16 $\left({ }^{16} \mathrm{O}\right)$, in samples to the respective ratios in a standard water (Friedman and O'Neil, 1977). Vienna Standard Mean Ocean Water (VSMOW) was used as the standard water (Gonfiantini, 1978). A negative value of $\delta \mathrm{D}$ (or $\delta^{18} \mathrm{O}$ ) thus represents water with less $\mathrm{D}$ relative to ${ }^{1} \mathrm{H}$ (or less ${ }^{18} \mathrm{O}$ relative to ${ }^{16} \mathrm{O}$ ) than VSMOW. A zero value of $\delta \mathrm{D}\left(\right.$ or $\left.\delta^{18} \mathrm{O}\right)$ represents water that has the same ratio of $\mathrm{D}$ to ${ }^{1} \mathrm{H}$ (or ${ }^{18} \mathrm{O}$ to ${ }^{16} \mathrm{O}$ ) as VSMOW.

\section{TESTING OF CRYODISTILLATION APPARATUS}

The cryodistillation apparatus was tested for potential artifacts by adding water of known tritium concentrations to oven-dried sediments collected at a depth of $11.9 \mathrm{~m}$ from UZB-1 and at depths of 48.2 and $72.5 \mathrm{~m}$ from UZB-2. The sediments were dried overnight at about $104^{\circ} \mathrm{C}$ in a forced-convection oven. About $160 \mathrm{~g}$ of distilled water was mixed with about $1.8 \mathrm{~kg}$ of oven-dry sediment that had cooled to room temperature in a sealed container. This mixture produced a water content approximately equal to the field water content. The mixture was allowed to equilibrate overnight. Then the mixture was packed into a $15-\mathrm{cm}$ long brass liner identical to the liner used for core samples. Water was extracted in the cryodistillation apparatus as described in the previous section. Two batches of distilled water were used. One was spiked with tritium and had a measured concentration of about 535 TU (two analyses gave 533 and $538 \mathrm{TU}$, table 1). The unspiked batch had a measured concentration of 6.6 TU. The low tritium water was added to samples from 11.9 and $48.2 \mathrm{~m}$. The high tritium water was added to samples from 11.9 and $72.5 \mathrm{~m}$. The experiment on the sample from $72.5 \mathrm{~m}$ was repeated to test for reproducibility.

The efficiency of the cryodistillation method was tested by (1) comparing the quantity of water lost during cryodistillation with the weight of ice collected in the flask (trap efficiency); (2) determining the quantity of water that remained in the sample following cryodistillation (residual water); and (3) comparing the isotopic composition of the water added to the sediments with the isotopic composition of the water recovered from the sediments. Residual water is expressed as a percentage of the total weight of water. The total weight of water is defined as the weight lost during cryodistillation plus the weight lost during oven drying after cryodistillation. Trap efficiency and residual water were measured for each extraction.

Results of the tests are summarized in table 1. Trap efficiency for all samples was greater than 97 percent. Residual water was \pm 0.3 percent. These results indicate that virtually all of the water was extracted 
Table 1. Trap efficiency, residual water, and isotopic composition of water added to and removed from oven-dried sediments from test holes UZB-1 and UZB-2 near burial area for low-level radioactive waste south of Beatty, Nev.

[Location of test holes is shown in figure IB]

\begin{tabular}{|c|c|c|c|c|c|c|c|c|c|}
\hline \multirow[b]{2}{*}{ Sample ${ }^{1}$} & \multirow{2}{*}{$\begin{array}{l}\text { Sample } \\
\text { depth } \\
\text { (meters } \\
\text { below } \\
\text { land } \\
\text { surface) }\end{array}$} & \multirow{2}{*}{$\begin{array}{c}\text { Trap } \\
\text { efficiency } \\
\text { (percent) }\end{array}$} & \multirow{2}{*}{$\begin{array}{l}\text { Residual } \\
\text { water }^{3} \\
\text { (percent) }\end{array}$} & \multicolumn{2}{|c|}{$\begin{array}{l}\text { Tritium concentration } \\
\text { (tritium units) }\end{array}$} & \multicolumn{2}{|c|}{$\begin{array}{l}\text { Deuterium }{ }^{5} \\
\text { ( } \mathrm{DD} \text {, permil) }\end{array}$} & \multicolumn{2}{|c|}{$\begin{array}{c}\text { Oxygen-18 } \\
\left(\delta^{18} \mathrm{O}, \text { permil }\right)\end{array}$} \\
\hline & & & & $\begin{array}{l}\text { Water } \\
\text { added to } \\
\text { sample }\end{array}$ & $\begin{array}{c}\text { Water } \\
\text { extracted } \\
\text { by cryo- } \\
\text { distillation }\end{array}$ & $\begin{array}{l}\text { Water } \\
\text { added to } \\
\text { sample }\end{array}$ & $\begin{array}{c}\text { Water } \\
\text { extracted } \\
\text { by cryo- } \\
\text { distillation }\end{array}$ & $\begin{array}{l}\text { Water } \\
\text { added to } \\
\text { sample }\end{array}$ & $\begin{array}{c}\text { Water } \\
\text { extracted } \\
\text { by cryo- } \\
\text { distillation }\end{array}$ \\
\hline 1 & 11.9 & 99 & -0.3 & $6.6 \pm 1.2$ & $11.6 \pm 1.4$ & -108 & -109 & -14.7 & -14.8 \\
\hline 2 & 11.9 & 100 & -0.1 & $533 \pm 14$ & $491 \pm 14$ & -108 & -108 & -15.1 & -15.3 \\
\hline 3 & 48.2 & 97 & -0.2 & $6.6 \pm 1.2$ & $9.6 \pm 1.4$ & -108 & -111 & -14.7 & -15.1 \\
\hline 4 & 72.5 & 100 & 0.2 & $533 \pm 14$ & $500 \pm 14$ & -108 & -105 & -15.1 & -14.8 \\
\hline 5 & 72.5 & 99 & -0.2 & $538 \pm 20$ & $516 \pm 20$ & -110 & -111 & -15.3 & -15.6 \\
\hline
\end{tabular}

${ }^{1}$ Samples 1 and 2 were from test hole UZB-I. Samples 3 through 5 were from test hole UZB-2.

${ }^{2}$ Trap efficiency is ratio of weight of water collected in freeze trap to weight lost during cryodistillation, reported as a percentage.

${ }^{3}$ Residual water is ratio of weight lost during cryodistillation to total weight of water, reported as a percentage. Total weight of water equals weight lost during cryodistillation plus weight lost during oven drying after cryodistillation.

${ }^{4}$ Tritium units can be converted to picocuries per liter by multiplying tritium units by 3.2 (Fritz and Fontes, 1980, p. 14). Error associated with each tritium value represents the two-standard-deviation (two-sigma) counting uncertainty. Water used for sample 5 was from same batch but was analyzed separately from water used for samples 2 and 4. Analyses were made by Robert Michel, U.S. Geological Survey, Water Resources Division isotope laboratory, Menlo Park, Calif.

${ }^{5}$ Deuterium and oxygen- 18 values are reported using delta $(\delta)$ notation in permil relative to Vienna Standard Mean Ocean Water. Twostandard deviation (two-sigma) precision of deuterium and oxygen-18 analyses are 2 and 0.2 permil, respectively. Analyses were made by Lloyd White, U.S. Geological Survey, Water Resources Division isotope laboratory, Menlo Park, Calif.

from the sediment, and that most of the extracted water was captured in the trap. Negative values of residual water mean samples gained weight during oven drying.

The $\delta \mathrm{D}$ and $\delta^{18} \mathrm{O}$ values of water extracted from sediments were about the same as those of added water, with no consistent trends in the differences. The largest difference was an increase in $\delta \mathrm{D}$ of 3 permil for the high-tritium water extracted from the 72.5-m sample and a decrease in $\delta^{18} \mathrm{O}$ of 0.4 permil for the low-tritium water extracted from the 48.2-m sample. These differences were less than the two standard-deviation (two sigma) precision of $\delta \mathrm{D}$ and $\delta^{18} \mathrm{O}$ determinations.

In the low-tritium experiments, concentrations in extracted water were greater by 3 to 5 TU than the concentration in the added water. In the high-tritium experiments, concentrations in extracted water were lower by 22 to 42 TU than the concentration in the added water. In all but one test (the repeated test on the 72.5-1n sample), the observed differences exceeded the two sigma counting uncertainty.

Likely reasons for these differences include isotopic exchange with hydroxyl and other hydrogencontaining groups at mineral surfaces (Halevy, 1964; Gvirtzınan and Magaritz, 1986) and isotopic exchange with tightly bound water at mineral surfaces.
Additional (but less likely) reasons include fractionation effects due to incomplete volatilization or recovery of water during cryodistillation, contamination during sample processing, isotopic exchange with atmospheric water, contamination by atmospheric water, and cross contamination between samples.

Because of its exceedingly low abundance, tritium is more sensitive to contamination than is D or ${ }^{18} \mathrm{O}$. The largest observed difference, $42 \mathrm{TU}$, represents a difference of 42 tritium atoms per $10^{18}$ hydrogen atoms. A difference of $42 \mathrm{D}$ atoms per $10^{18}$ hydrogen atoms (or $42^{18} \mathrm{O}$ atoms per $10^{18}$ oxygen atoms) would produce a change of less than one billionth of a permil in $\delta \mathrm{D}$ or $\delta^{18} \mathrm{O}$.

Although the reason for the differences in tritium concentrations between extracted water and water added to sediments is not known, the low-tritium experiments agreed within 3 to 5 TU. In contrast, the high-tritium experiments differed by 20 to $45 \mathrm{TU}$. Because of the higher tritium concentration in the added water, these experiments agreed within 4 to 8 percent. Concentrations of tritium in water extracted by cryodistillation from UZB-1 and UZB-2 sediments thus appear to give reasonable indications of tritium concentrations in the original pore water. 


\section{DISTRIBUTION OF TRITIUM, DEUTERIUM, AND OXYGEN-18}

Cryodistillation results for UZB-1 and UZB-2 core samples are listed in table 2 . Residual water ranged from -0.6 to +0.7 percent, indicating that most of the water was removed from the sediments during cryodistillation. Trap efficiency ranged from 94 to 100 percent, indicating that most of the water evaporated from core samples was captured in the freeze trap. The actual range in trap efficiency may be less because seven core samples were weighed with the thermal insulation before and after cryodistillation. Subsequent measurements showed that the thermal insulation lost about $7 \mathrm{~g}$ during cryodistillation.
Trap efficiency for five core samples that were weighed before and after cryodistillation without thermal insulation ranged from 98.3 to 99.3 percent.

Figure 5 compares the gravimetric water content of UZB- 1 and UZB-2 cores determined at the time of cryodistillation (March 1996) with that of adjacent cores determined shortly after sampling (January 1993 for UZB-1 cores and February 1994 for UZB-2 cores). Maximum differences in water content for adjacent cores were +0.023 gram water per gram oven-dry sediment at $8.9 \mathrm{~m}$ and -0.013 gram water per gram ovendry sediment at $11.7 \mathrm{~m}$. The close agreement between the two data sets indicates that water contents did not change appreciably during storage.

Table 2. Trap efficiency, residual water, and isotopic composition of pore water extracted from cores collected from test holes UZB-1 and UZB-2 near burial area for low-level radioactive waste south of Beatty, Nev.

[Location of test holes is shown on figure $1 B$ ]

\begin{tabular}{|c|c|c|c|c|c|c|c|}
\hline $\begin{array}{l}\text { Core interval } \\
\text { (meters below } \\
\text { land surface) }\end{array}$ & $\begin{array}{l}\text { Date core } \\
\text { collected }\end{array}$ & $\begin{array}{c}\text { Date } \\
\text { water } \\
\text { extracted }\end{array}$ & $\begin{array}{c}\text { Trap } \\
\text { efficiency } \\
\text { (percent) }\end{array}$ & $\begin{array}{c}\text { Residual } \\
\text { water }^{2} \\
\text { (percent) }\end{array}$ & $\begin{array}{c}\text { Tritium } \\
\text { concentration } \\
\text { (tritium units) }\end{array}$ & $\begin{array}{l}\text { Deuterium }^{4} \\
\text { ( } \delta \mathrm{D}, \text { permil) }\end{array}$ & $\begin{array}{c}\text { Oxygen-18 } \\
\left(\delta^{18} 0 \text {, permil) }\right.\end{array}$ \\
\hline \multicolumn{8}{|c|}{ Test hole UZB-1 } \\
\hline $2.75-2.90$ & $11 / 18 / 92$ & $03 / 13 / 96$ & 99.1 & -0.6 & $473 \pm 36$ & -64 & 0.4 \\
\hline $5.85-6.00$ & $11 / 18 / 92$ & $03 / 13 / 96$ & 99.3 & -0.5 & $70 \pm 24$ & -76 & -3.4 \\
\hline $9.09-9.24$ & $11 / 18 / 92$ & $03 / 14 / 96$ & ${ }^{5} 97$ & 0.1 & $198+28$ & -81 & -5.6 \\
\hline $11.86-12.01$ & $11 / 18 / 92$ & $03 / 13 / 96$ & 98.3 & 0.1 & $148 \pm 28$ & -85 & -5.4 \\
\hline $15.18-15.33$ & $11 / 18 / 92$ & $03 / 14 / 96$ & $5_{97}$ & -0.2 & $198 \pm 28$ & -102 & -10.6 \\
\hline $17.99-18.14$ & $11 / 18 / 92$ & $03 / 14 / 96$ & $5_{96}$ & 0.4 & $278 \pm 32$ & -101 & -11.3 \\
\hline $21.03-21.18$ & $11 / 19 / 92$ & $03 / 15 / 96$ & ${ }^{5} 100$ & 0.0 & $257 \pm 32$ & -106 & -11.4 \\
\hline \multicolumn{8}{|c|}{ Test hole UZB-2 } \\
\hline $36.40-36.55$ & $09 / 09 / 93$ & $03 / 15 / 96$ & ${ }^{5} 98$ & -0.3 & $98 \pm 28$ & -110 & -12.8 \\
\hline $48.47-48.62$ & $09 / 09 / 93$ & $03 / 15 / 96$ & ${ }^{5} 100$ & -0.1 & $46 \pm 24$ & -110 & -13.4 \\
\hline $60.69-60.84$ & $09 / 10 / 93$ & $03 / 15 / 96$ & $5_{94}$ & 0.2 & ${ }^{6} 9.0 \pm 3.2$ & -110 & -14.2 \\
\hline $72.54-72.69$ & $09 / 10 / 93$ & $03 / 27 / 96$ & 98.6 & 0.7 & ${ }^{6} 4.3 \pm 3.2$ & $7-101$ & $7-10.4$ \\
\hline $85.13-85.28$ & $09 / 10 / 93$ & $03 / 27 / 96$ & 98.6 & -0.6 & ${ }^{6} 1.3 \pm 2.4$ & -110 & -14.1 \\
\hline
\end{tabular}

${ }^{1}$ Trap efficiency is ratio of weight of water collected in freeze trap to weight lost from core during cryodistillation, reported as a percentage.

${ }^{2}$ Residual water is ratio of weight lost during cryodistillation to total weight of water, reported as a percentage. Total weight of water equals weight lost during cryodistillation plus weight lost during oven drying after cryodistillation.

${ }^{3}$ Tritium units can be converted to picocuries per liter by multiplying tritium units by 3.2 (Fritz and Fontes, 1980, p. 14). Error associated with each tritium value represents the two-standard-deviation (two-sigma) counting uncertainty. Analyses were made by Robert Michel, U.S. Geological Survey, Water Resources Division isotope laboratory, Menlo Park, Calif.

${ }^{4}$ Deuterium and oxygen-18 values are reported using delta $(\delta)$ notation in permil relative to Vienna Standard Mean Ocean Water. Two-standard deviation (two-sigma) precision of deuterium and oxygen- 18 analyses are 2 and 0.2 permil, respectively. Analyses were made by Lloyd White, U.S. Geological Survey, Water Resources Division isotope laboratory, Menlo Park, Calif.

${ }^{5}$ Samples were weighed with thermal insulation before and after cryodistillation. Thermal insulation lost weight during cryodistillation. Average loss from thermal insulation on four cells during an experiment on June 8, 1996, was 6.6 grams. Trap efficiencies for samples completed March 14-15, 1996, are estimates based on average loss from thermal insulation measured on June 8.

${ }^{6}$ Water was enriched prior to analysis of tritium concentration.

${ }^{7}$ Sample was transferred from two 7.5-centimeter long brass liners into one 15-centimeter long liner prior to cryodistillation. Paraffin coating and plastic cap on one liner was cracked. All other core samples had seals that were intact and were cryodistilled in the 15-centimeter long liners in which they were collected. 


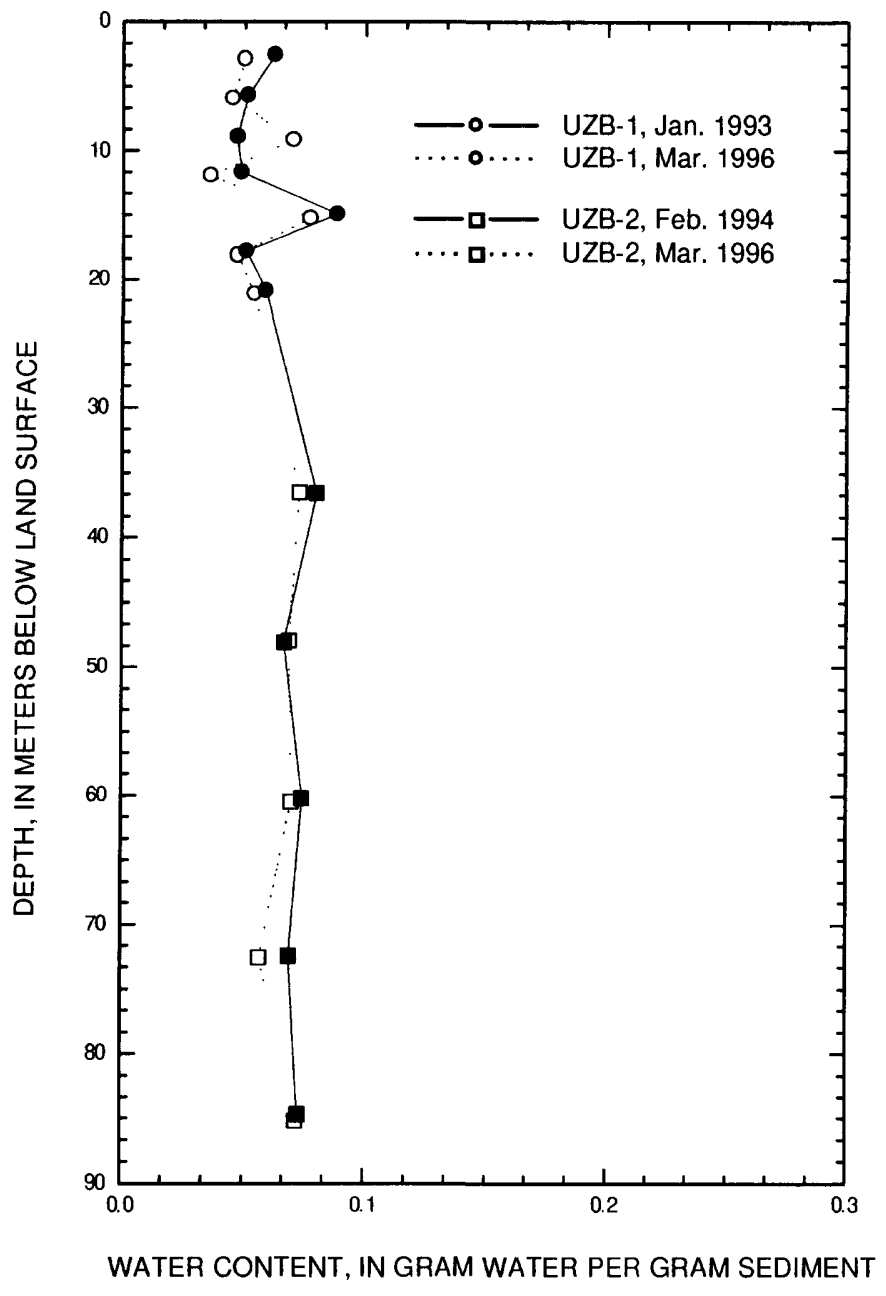

Figure 5. Gravimetric water content of UZB-1 and UZB-2 core samples determined by oven drying in January 1993 and February 1994 and by cryodistillation in March 1996. Test holes UZB-1 and UZB-2 are near low-level radioactive-waste burial site south of Beatty, Nev.

Tritium concentrations in table 2 have been adjusted to the appropriate sampling dates to account for decay between the times the core samples were collected and the times when the water extracted from them was analyzed for tritium. Tritium concentrations at time of sample collection $\left(C_{c}\right)$ were computed using the following equation (Robert L. Michel, U.S. Geological Survey, oral commun., 1997):

$$
C_{c}=C_{a} / e^{-\lambda t}
$$

where $C_{a}$ is the tritium concentration at time of analysis, in tritium units,

$\lambda$ is the decay constant for tritium, $\ln (2) /(12.43$ years), and

$t$ is the time from collection to analysis, in years.
The highest tritium concentration, 473 TU, was measured in water from the shallowest core sample, at $2.8 \mathrm{~m}$ (fig. 6). Tritium concentration declined to $70 \mathrm{TU}$ in the next core sample, at $6 \mathrm{~m}$, then increased to 278 $\mathrm{TU}$ at $18 \mathrm{~m}$ before declining again to $4.3 \mathrm{TU}$ at a depth of $72 \mathrm{~m}$. Water from the deepest core sample, at $85 \mathrm{~m}$, had a tritium concentration of $1.3 \mathrm{TU}$. This was less than the two-sigma counting uncertainty of $2.4 \mathrm{TU}$ (table 2).

Tritium concentrations in water vapor extracted in May 1996 from UZB-2 air ports generally increased from previous samplings (fig. 6). Table 3 lists May 1996 tritium concentrations for UZB-2 along with May 1996 concentrations for samples collected from probes $\mathrm{B}$ and $\mathrm{C}$ (fig. $1 B$ ). The concentration of tritium in a sample collected May 10-17 from the $1.68-\mathrm{m}$ probe at UZB-2 was 20,600 TU. This is more than 15 times larger than that of any other sample collected from UZB-2. These observations indicate the presence of a bimodal distribution of tritium with the highest concentration at a depth of $1.68 \mathrm{~m}$ (fig. 6).

The largest observed tritium concentration was from probe $B$ at a depth of $1.8 \mathrm{~m}$ near the security fence (fig. $1 B$ ). Here the tritium concentration was about $29,000 \mathrm{TU}$ on the basis of three samples collected May 10-17 (table 3). This value was nearly the same as the tritium concentration in a vapor sample collected during July 1995 at the same location (Prudic and Striegl, 1995, p. 4).

The profiles of the stable isotopes of water are simpler than those of tritium. The $\delta \mathrm{D}$ and $\delta^{18} \mathrm{O}$ values in core water generally become lower (more negative) with depth (table 2; fig. 7) and are nearly uniform below a depth of $30 \mathrm{~m}$. An exception is the sample from 72.54-72.69 m. This sample was transferred from two $7.5-\mathrm{cm}$-long brass liners into one 15-cm-long liner before cryodistillation. The paraffin coating and plastic cap on one of the two 7.5-cm core samples was cracked. Evaporation during storage might explain the heavier isotopic composition compared to the other core samples from similar depths. All other core samples were cryodistilled in their original $15-\mathrm{cm}$ long liners and had seals that were intact.

The $\delta \mathrm{D}$ and $\delta^{18} \mathrm{O}$ values for UZB-2 water vapor collected in April 1994, July 1995, and May 1996 are listed in table 4 . Profiles of $\delta \mathrm{D}$ and $\delta^{18} \mathrm{O}$ in water vapor from UZB-2 roughly parallel corresponding profiles in core water but are shifted about -63 permil in $\delta \mathrm{D}$ and -9 permil in $\delta^{18} \mathrm{O}$ (fig. 7). 


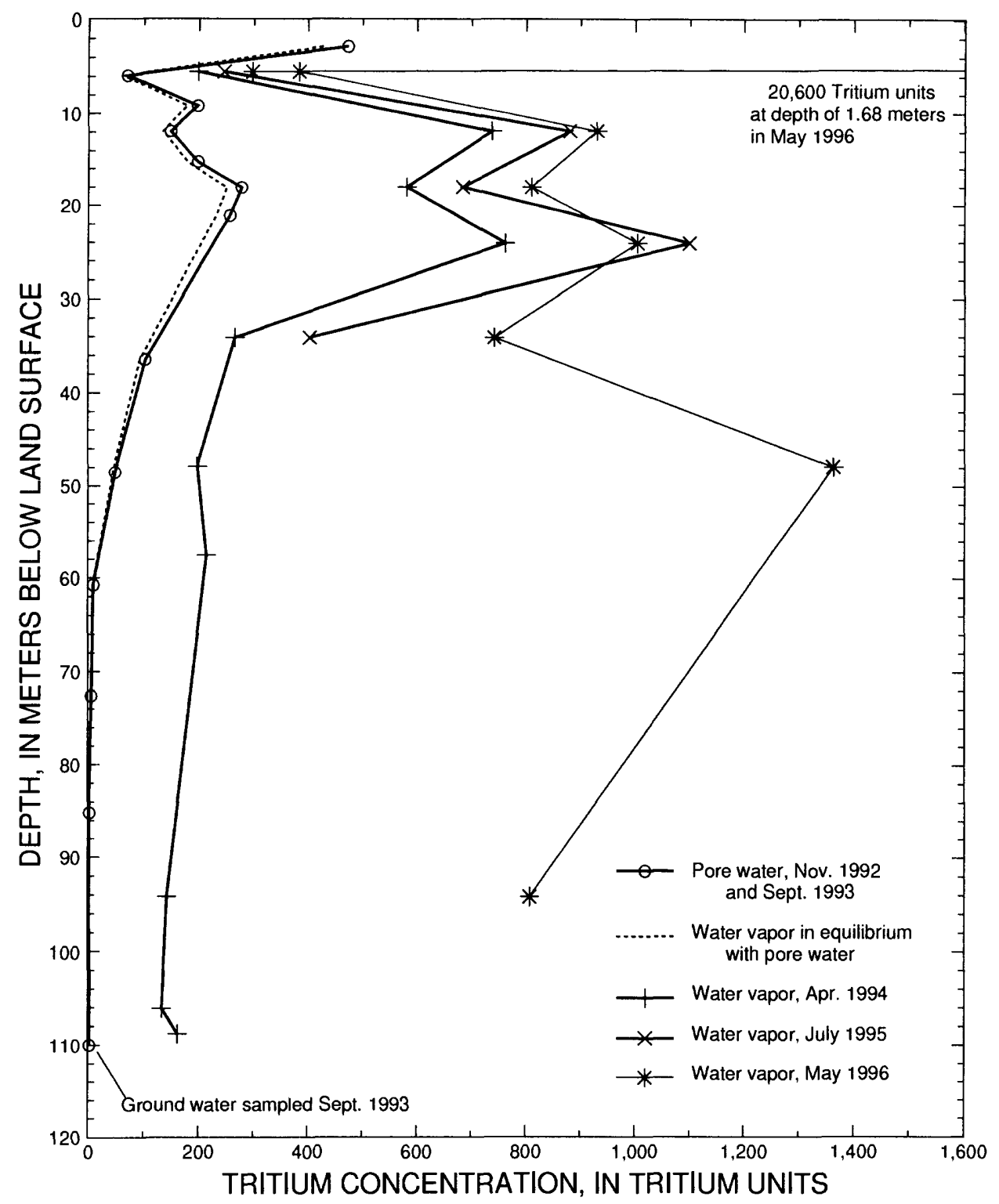

Figure 6. Tritium concentration in water extracted from UZB-1 and UZB-2 core samples collected November 1992 and September 1993, respectively, and in water vapor from UZB-2 collected April 1994, July 1995, and May 1996. Sample at depth of 1.68 meters for May 1996 was from a shallow probe near UZB-2. Equilibrium values for water vapor (dotted line) were calculated on the basis of temperatures measured in test holes UZB-1 and UZB-2. Test holes UZB-1 and UZB-2 are near low-level radioactive-waste burial site south of Beatty, Nev.

Table 4 also lists $\delta \mathrm{D}$ and $\delta^{18} \mathrm{O}$ values for water vapor collected from the shallow probes. These values were similar at all three shallow-probe locations (table 4). The $\delta \mathrm{D}$ and $\delta^{18} \mathrm{O}$ values are higher in water vapor from the shallow probes than in vapor from greater depths, indicating water that is isotopically heavier. The higher values indicate that water vapor originates from pore water that is more evaporated than water vapor sampled from deeper depths.

\section{Comparison of Core Water to Ground Water and Precipitation}

Tritium concentrations in ground-water samples collected from UZB-2 when it was drilled in September 1993, six nearby wells in August 1989, and four other wells in December 1992 (table 5; fig. 1B) are less than the concentration in present-day precipitation (about 15 TU; Yang and others, 1996). The low tritium 
Table 3. Tritium concentration in water vapor from unsaturated sediments near burial area for low-level radioactive waste south of Beatty, Nev., May 1996

[Location of test hole UZB-2 and shallow probes is shown on figure $1 B$ ]

\begin{tabular}{|c|c|c|c|c|}
\hline \multicolumn{2}{|c|}{ Depth $^{1}$} & \multirow[b]{2}{*}{ Date sampled } & \multirow{2}{*}{$\begin{array}{c}\text { Tritium concentration }{ }^{2} \\
\text { (tritium units) }\end{array}$} & \multirow{2}{*}{$\begin{array}{l}\text { Counting uncertainty } \\
\text { (tritium units) }\end{array}$} \\
\hline $\begin{array}{l}\text { Meters below } \\
\text { land surface }\end{array}$ & $\begin{array}{l}\text { Feet below } \\
\text { land surface }\end{array}$ & & & \\
\hline \multicolumn{5}{|c|}{ Test hole UZB-2 } \\
\hline 5.5 & 18 & $5 / 10$ to $5 / 14 / 96$ & 384 & \pm 26 \\
\hline 5.5 & 18 & $5 / 14$ to $5 / 17 / 96$ & 298 & \pm 26 \\
\hline 11.9 & 39 & $5 / 10$ to $5 / 14 / 96$ & 930 & \pm 38 \\
\hline 11.9 & 39 & $5 / 14$ to $5 / 17 / 96$ & 930 & \pm 38 \\
\hline 18.0 & 59 & $5 / 10$ to $5 / 17 / 96$ & 810 & \pm 36 \\
\hline 24.1 & 79 & $5 / 10$ to $5 / 14 / 96$ & 1,005 & \pm 40 \\
\hline 24.1 & 79 & $5 / 14$ to $5 / 17 / 96$ & 1,006 & \pm 40 \\
\hline 34.1 & 112 & $5 / 10$ to $5 / 17 / 96$ & 742 & \pm 34 \\
\hline 47.9 & 157 & $5 / 10$ to $5 / 17 / 96$ & 1,363 & \pm 46 \\
\hline 94.2 & 309 & $5 / 10$ to $5 / 17 / 96$ & 808 & \pm 36 \\
\hline \multicolumn{5}{|c|}{ Shallow probe near UZB-2 } \\
\hline 1.68 & 5.5 & $5 / 10$ to $5 / 17 / 96$ & 20,600 & \pm 400 \\
\hline \multicolumn{5}{|c|}{ Shallow probe B } \\
\hline 1.8 & 5.9 & $5 / 10$ to $5 / 13 / 96$ & 29,220 & \pm 560 \\
\hline & & $5 / 13$ to $5 / 14 / 96$ & 29,710 & \pm 580 \\
\hline & & $5 / 14$ to $5 / 17 / 96$ & 28,830 & \pm 560 \\
\hline \multicolumn{5}{|c|}{ Shallow probe $C$} \\
\hline 2.0 & 6.6 & $5 / 10$ to $5 / 13 / 96$ & 16,570 & \pm 340 \\
\hline & & $5 / 13$ to $5 / 14 / 96$ & 16,830 & \pm 340 \\
\hline & & $5 / 14$ to $5 / 16 / 96$ & 16,480 & \pm 320 \\
\hline
\end{tabular}

\footnotetext{
${ }^{1}$ Depths in feet are given for cross reference to depths used by Prudic and Striegl (1995).

${ }^{2}$ Tritium units can be converted to picocuries per liter by multiplying tritium units by 3.2 (Fritz and Fontes, 1980, p. 14). Analyses were made by Robert Michel, U.S. Geological Survey, Water Resources Division isotope laboratories, Menlo Park, Calif.

${ }^{3}$ Error associated with each tritium value represents the two-standard-deviation (two-sigma) counting uncertainty.
}

concentrations in ground water near UZB-2 indicate that ground water is not the source of tritium in the unsaturated zone.

Most of the tritium observed in the profile cannot be explained by infiltration of precipitation at the site. Because of atmospheric nuclear testing, which began in 1952 and ended in 1963, tritium concentrations in precipitation exceeded 1,000 TU during the early 1960's (Yang and others, 1996, p. 25 and 53). Volumeaveraged tritium concentrations in precipitation peaked at about 1,800 TU in 1963 and 1964 during which time precipitation at Beatty, Nev., totaled $19 \mathrm{~cm}$ (Nichols, 1987, p. 16). If all the precipitation from 1963 and 1964 entered the ground and moved piston-like, completely displacing pre-existing pore water, then at the prevailing volumetric water content of $0.07 \mathrm{~cm}^{3} / \mathrm{cm}^{3}$ this would produce a $2.7-\mathrm{m}$ thick interval with a tritium concentration of 340 TU (after accounting for decay). Mixing of precipitation with older or younger water would reduce this concentration. Tritium in the shallowest core sample (473 TU; table 2 ) exceeded this maximum potential concentration from precipitation.

The relation of $\delta \mathrm{D}$ and $\delta^{18} \mathrm{O}$ in core water to that in ground water and precipitation is shown in figure 8 . The $\mathrm{D}$ and ${ }^{18} \mathrm{O}$ values of the 11 ground-water samples lie in narrow ranges spanning roughly twice the respective analytical precisions. Because analytical precision is only one component of total measurement error, the hypothesis of no difference among ground-water samples should not be rejected.

Water in the deepest core sample (85.13-85.28 m) had $\delta \mathrm{D}$ and $\delta^{18} \mathrm{O}$ values nearly identical to those in ground water (figs. 7, 8; tables 2, 5). Ground water from UZB-2 collected at the time of drilling 

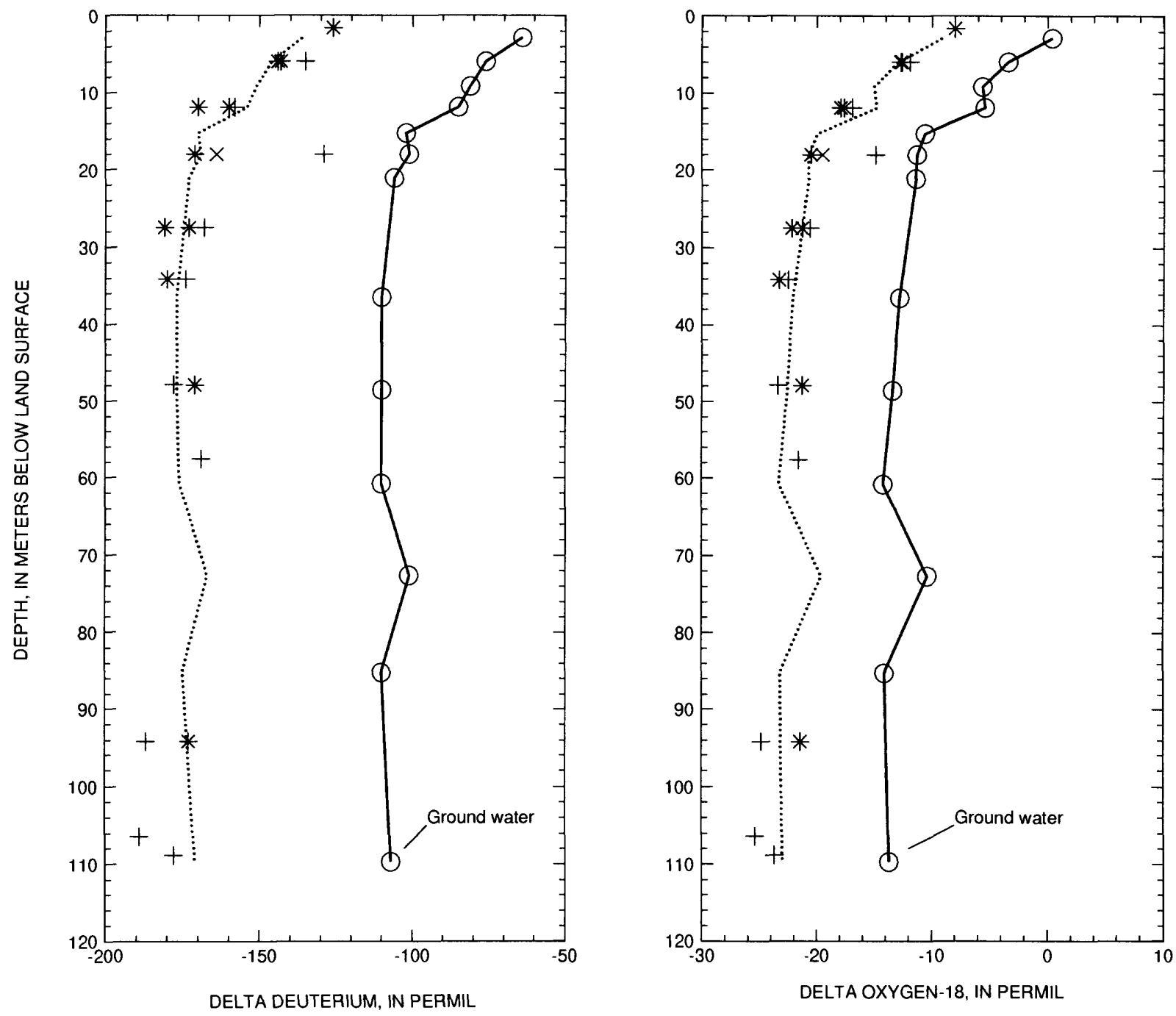

EXPLANATION

Pore water, November 1992

and September 1993

Water vapor in equilibrium with pore water

$+\quad$ Water vapor, April 1994

$\times \quad$ Water vapor, July 1995

* Water vapor, May 1996

Figure 7. Distribution of deuterium and oxygen-18 in water extracted from UZB-1 and UZB-2 core samples that were collected in November 1992 and September 1993, respectively, and in water vapor sampled from UZB-2 air ports in April 1994, July 1995, and May 1996. Equilibrium values for water vapor (dotted lines) were calculated on the basis of temperatures measured in UZB-1 and UZB-2. Test holes UZB-1 and UZB-2 are near lowlevel radioactive-waste burial site south of Beatty, Nev. 
Table 4. Deuterium and oxygen-18 composition of water vapor from unsaturated sediments near burial area for low-level radioactive waste south of Beatty, Nev., in April 1994, July 1995, and May 1996

[Location of sampling sites shown on figure $\mid B$ ]

\begin{tabular}{|c|c|c|c|c|}
\hline \multicolumn{2}{|c|}{ Depth $^{1}$} & \multirow[b]{2}{*}{ Date sampled } & \multirow{2}{*}{$\begin{array}{l}\text { Deuterium }{ }^{2,3} \\
\text { ( } \delta \mathrm{D}, \text { permil) }\end{array}$} & \multirow{2}{*}{$\begin{array}{c}\text { Oxygen-18 } \\
\left(\delta^{18} 0 \text {, permil }\right)\end{array}$} \\
\hline $\begin{array}{l}\text { Meters below } \\
\text { land surface }\end{array}$ & $\begin{array}{l}\text { Feet below } \\
\text { land surface }\end{array}$ & & & \\
\hline \multirow{4}{*}{5.5} & & Test hole UZB-2 & & \\
\hline & 18 & $4 / 15$ to $4 / 20 / 94$ & -135 & -11.9 \\
\hline & & $5 / 13$ to $5 / 14 / 96$ & -143 & -12.6 \\
\hline & & $5 / 14$ to $5 / 17 / 96$ & -144 & -12.7 \\
\hline \multirow[t]{3}{*}{11.9} & 39 & $4 / 15$ to $4 / 20 / 94$ & -158 & -16.9 \\
\hline & & $5 / 13$ to $5 / 14 / 96$ & -160 & -17.6 \\
\hline & & $5 / 14$ to $5 / 17 / 96$ & -170 & -17.9 \\
\hline \multirow[t]{3}{*}{18.0} & 59 & $4 / 15$ to $4 / 20 / 94$ & -129 & -14.9 \\
\hline & & $7 / 09$ to $7 / 10 / 95$ & -164 & -19.5 \\
\hline & & $5 / 13$ to $5 / 14 / 96$ & -171 & -20.5 \\
\hline \multirow[t]{3}{*}{24.1} & 79 & $4 / 15$ to $4 / 19 / 94$ & -168 & -20.6 \\
\hline & & $5 / 13$ to $5 / 14 / 96$ & -173 & -21.3 \\
\hline & & $5 / 14$ to $5 / 17 / 96$ & -181 & -22.2 \\
\hline \multirow[t]{2}{*}{34.1} & 112 & $4 / 15$ to $4 / 19 / 94$ & -174 & -22.5 \\
\hline & & $5 / 13$ to $5 / 14 / 96$ & -180 & -23.3 \\
\hline \multirow[t]{2}{*}{47.9} & 157 & $4 / 16$ to $4 / 20 / 94$ & -178 & -23.4 \\
\hline & & $5 / 13$ to $5 / 14 / 96$ & -171 & -21.3 \\
\hline 57.6 & 189 & $4 / 15$ to $4 / 20 / 94$ & -169 & -21.6 \\
\hline \multirow[t]{2}{*}{94.2} & 309 & $4 / 16$ to $4 / 20 / 94$ & -187 & -24.8 \\
\hline & & $5 / 13$ to $5 / 14 / 96$ & -173 & -21.4 \\
\hline 106.4 & 349 & $4 / 15$ to $4 / 19 / 94$ & -189 & -25.4 \\
\hline 108.8 & 357 & $4 / 16$ to $4 / 20 / 94$ & -178 & -23.7 \\
\hline \multicolumn{5}{|c|}{ Shallow probe near UZB-2 } \\
\hline \multirow[t]{2}{*}{1.68} & 5.5 & $5 / 10$ to $5 / 13 / 96$ & -126 & -8.0 \\
\hline & & Shallow probe B & & \\
\hline \multirow[t]{3}{*}{1.8} & 5.9 & $5 / 10$ to $5 / 13 / 96$ & -129 & -7.5 \\
\hline & & $5 / 13$ to $5 / 14 / 96$ & -124 & -7.3 \\
\hline & & $5 / 14$ to $5 / 17 / 96$ & -125 & -7.6 \\
\hline \multirow{4}{*}{2.0} & & Shallow probe $\mathrm{C}$ & & \\
\hline & 6.6 & $5 / 10$ to $5 / 13 / 96$ & -123 & -6.2 \\
\hline & & $5 / 13$ to $5 / 14 / 96$ & -121 & -5.9 \\
\hline & & $5 / 14$ to $5 / 16 / 96$ & -121 & -6.0 \\
\hline
\end{tabular}

${ }^{1}$ Depths in feet are given for cross reference to depths used by Prudic and Striegl (1995).

${ }^{2}$ Deuterium and oxygen- 18 values are reported using delta $(\delta)$ notation in permil relative to Vienna Standard Mean Ocean Water. Two-standard deviation (two-sigma) precision of deuterium and oxygen- 18 analyses are 2 and 0.2 permil, respectively. Samples collected in April 1994 were analyzed by Jessica Hopple, U.S. Geological Survey, Water Resources Division isotope laboratory, Reston, Va.; samples collected in July 1995 and May 1996 were analyzed by Lloyd White. U.S. Geological Survey, Water Resources Division isotope laboratory, Menlo Park, Calif.

${ }^{3}$ Samples collected in April 1994 were analyzed using a hydrogen equilibration technique (Coplen and others, 1991). Samples collected in July 1995 and May 1996 were analyzed using a zinc reduction technique (Kendall and Coplen, 1985).

${ }^{4}$ Samples were analyzed using a carbon-dioxide gas equilibration technique (Epstein and Mayeda, 1953). 
Table 5. Tritium concentration and deuterium and oxygen-18 composition of ground water from wells and test hole UZB-2 near burial area for low-level radioactive waste south of Beatty, Nev., August 1989, December 1992, and September 1993

[Location of wells is shown on figure 1B. Symbols: NA, not applicable; --, not determined]

\begin{tabular}{|c|c|c|c|c|c|c|}
\hline $\begin{array}{l}\text { Well or test } \\
\text { hole name }\end{array}$ & $\begin{array}{l}\text { Date well } \\
\text { sampled }\end{array}$ & $\begin{array}{l}\text { Screened interval } \\
\text { (meters below } \\
\text { land surface) }\end{array}$ & $\begin{array}{l}\text { Depth to water } \\
\text { in well } \\
\text { (meters below } \\
\text { land surface) }\end{array}$ & $\begin{array}{c}\text { Tritium } \\
\text { concentration }^{2} \\
\text { (tritium units) }\end{array}$ & $\begin{array}{l}\text { Deuterium }^{3} \\
\text { ( } \delta \mathrm{D}, \text { permil) }\end{array}$ & $\begin{array}{c}\text { Oxygen-18 } \\
\left(\delta^{18} 0 \text {, permil) }\right.\end{array}$ \\
\hline UZB- $2^{4}$ & $09 / 12 / 93$ & NA & 109.7 & $-3 \pm 10$ & -107 & -13.7 \\
\hline Site well & $08 / 14 / 89$ & $91-173$ & 85.3 & $0.4 \pm 0.6$ & -107 & -14.0 \\
\hline MR-3 & $08 / 16 / 89$ & $111-123$ & 112.2 & $3.8 \pm 0.6$ & -108 & -14.0 \\
\hline MR-3 & $08 / 17 / 89$ & $111-123$ & 112.2 & $2.0 \pm 0.6$ & -- & -- \\
\hline W001 & $12 / 08 / 92$ & $104-112$ & 105.2 & $0.2 \pm 0.2$ & -104 & -14.0 \\
\hline MW311 & $12 / 09 / 92$ & $91-98$ & 93.0 & $<0.1 \pm 0.2$ & -104 & -13.9 \\
\hline MW313 & $08 / 15 / 89$ & $86-92$ & 87.8 & $0.4 \pm 0.6$ & -107 & -13.9 \\
\hline MW314 & $08 / 18 / 89$ & $90-96$ & 92.4 & $0.9 \pm 0.6$ & -106 & -14.0 \\
\hline MW315 & $08 / 17 / 89$ & $92-98$ & 93.3 & $0.6 \pm 0.6$ & -105 & -14.0 \\
\hline MW316 & $08 / 18 / 89$ & $85-91$ & 89.0 & $0.7 \pm 0.6$ & -105 & -14.0 \\
\hline MW600 & $12 / 08 / 92$ & $141-144$ & 93.3 & $<0.1 \pm 0.2$ & -105 & -14.0 \\
\hline MW604 & $12 / 09 / 92$ & $126-130$ & 99.4 & $<0.1 \pm 0.2$ & -104 & -13.9 \\
\hline
\end{tabular}

${ }^{1}$ Depth to water in well was measured prior to pumping sample.

${ }^{2}$ Tritium units can be converted to picocuries per liter by multiplying tritium units by 3.2 (Fritz and Fontes, 1980, p. 14). Error associated with each tritium value represents the two-standard-deviation (two-sigma) counting uncertainty. Samples were processed through U.S. Geological Survey Central Laboratory, Arvada, Colo.

${ }^{3}$ Deuterium and oxygen-18 values are reported using delta $(\delta)$ notation in permil relative to Vienna Standard Mean Ocean Water. Twostandard deviation (two-sigma) precision of deuterium and oxygen-18 analyses are 2 and 0.2 permil, respectively. Samples were processed through U.S. Geological Survey Central Laboratory, Arvada, Colo.

${ }^{4}$ Sample was collected by lowering bailer below water table at time test hole drilled. Depth to water was measured about 4 hours after drilling stopped. Sample was analyzed by Robert Michel, U.S. Geological Survey, Water Resources Division isotope laboratory, Menlo Park, Calif.

(September 1993) had a $\delta \mathrm{D}$ of -107 permil and a $\delta^{18} \mathrm{O}$ of -13.7 permil. Ground-water samples collected in August 1989 from wells MR-3 and the site well (fig. $1 B$ ) had a $\delta \mathrm{D}-108$ and -107 permil, respectively, and a $\delta^{18} \mathrm{O}$ of -14.0 permil for both samples (table 5).

Although the isotopic composition of precipitation was not analyzed at the site, 16 precipitation samples collected about $35 \mathrm{~km}$ to the southeast from February 1984 through July 1985 were analyzed for $\delta \mathrm{D}$ and $\delta^{18} \mathrm{O}$ (Milne and others, 1987; fig. $1 A$ ). The mean composition for the 18-month period, weighted by the volume of precipitation, was -77 permil for $\delta \mathrm{D}$ and -10.3 permil for $\delta^{18} \mathrm{O}$. These values are similar to mean annual values reported for a station about $70 \mathrm{~km}$ east of the study site (Tyler and others, 1996). The altitude of the study site is $9 \mathrm{~m}$ lower than the precipitation station and about $113 \mathrm{~m}$ lower than the station reported by Tyler and others (1996).

Values to the right of the meteoric water line (fig. 8) usually indicate evaporation of meteoric water (Coplen, 1993, p. 235). Precipitation during the months of April through October is generally more enriched in $\mathrm{D}$ and ${ }^{18} \mathrm{O}$ (that is, heavier, more evaporated) than precipitation during the months of November through March.

Core water at depths less than $30 \mathrm{~m}$ is more evaporated (heavier) than core water at depths greater than $30 \mathrm{~m}$. Core water becomes increasingly enriched (heavier) in $\mathrm{D}$ and ${ }^{18} \mathrm{O}$ towards land surface (table 2), consistent with evaporative discharge of water at the land surface (Fischer, 1992). The deepest core waters (greater than $30 \mathrm{~m}$ ) have $\delta \mathrm{D}$ values that are less than all but one of the precipitation samples collected during the 18-month period February 1984 through July 1985. If the isotopic composition of precipitation for the 18-month period is representative of modern precipitation, then the deepest core waters are not from modern precipitation. Because the stable isotopes plot on an apparent evaporation trend (fig. 8), the source of core water is ground water or past precipitation of a similar isotopic composition. 


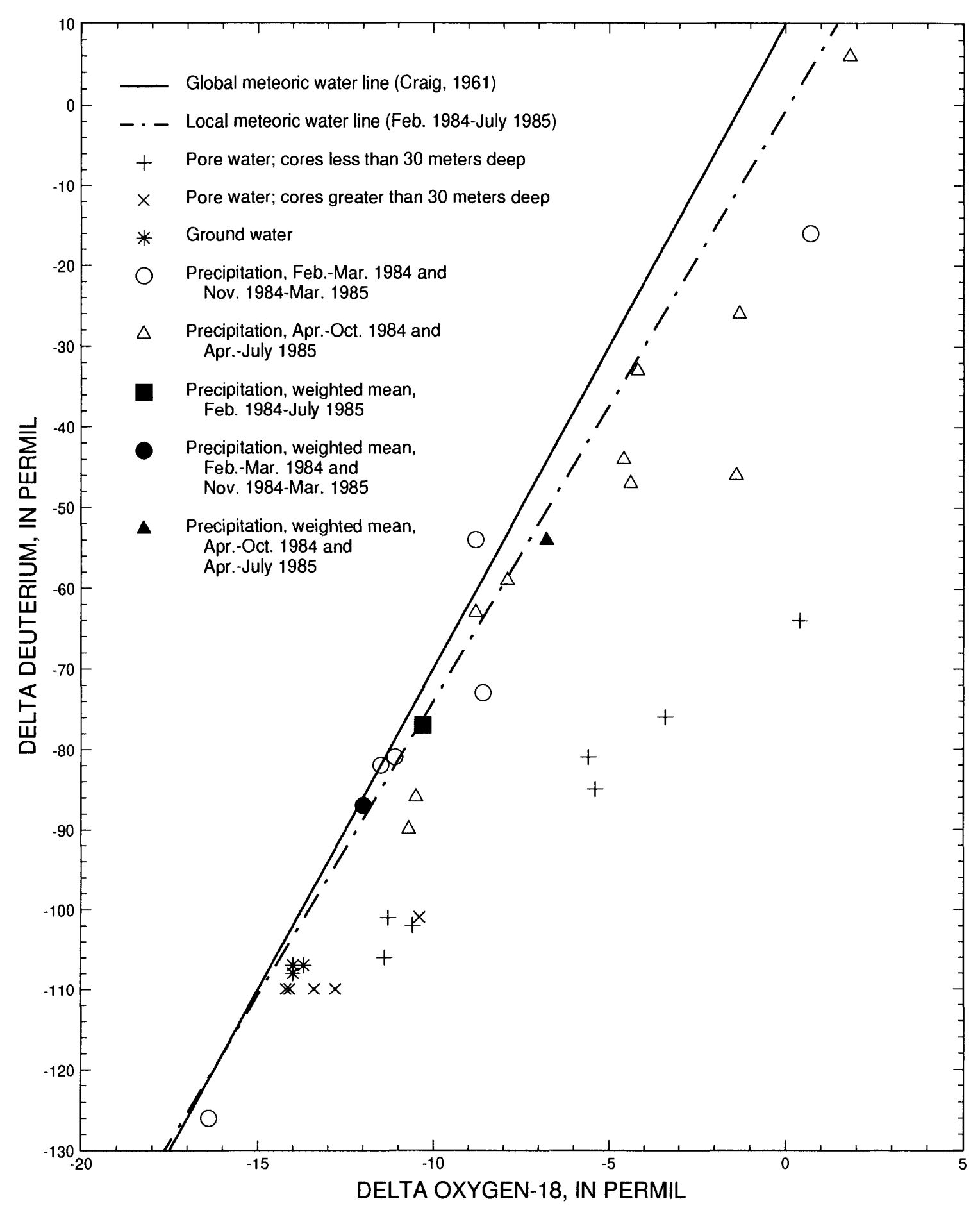

Figure 8. Relation between deuterium and oxygen-18 for (1) precipitation near Amargosa Valley, Nev. (from Milne and others, 1987) and (2) ground water from wells and core water from UZB-1 and UZB-2 near low-level radioactive-waste burial site south of Beatty, Nev. Meteoric water line from Craig (1961). 


\section{Effect of Isotopic Fractionation}

Fractionation causes water vapor in equilibrium with liquid water to be more depleted in the heavy isotopic species because of the lower vapor pressure of the heavier species (Ferronsky and Polyakov, 1982). The $\delta \mathrm{D}$ and $\delta^{18} \mathrm{O}$ values of water vapor in UZB-2 closely approximate expected values computed from measured values for liquid (core) water assuming equilibrium (dotted lines in fig. 7). The expected $\delta \mathrm{D}$ and $\delta^{18} \mathrm{O}$ values in water vapor were calculated using isotopic fractionation factors, $\alpha_{x}$ (Friedman and O'Neil, 1977). Expected $\delta \mathrm{D}$ and $\delta^{18} \mathrm{O}$ values of water vapor were calculated from:

$$
\delta x_{v}=\frac{1,000+\delta x_{l}}{\alpha_{x}}-(1,000),
$$

where $\alpha_{x}$ is the fractionation factor for $\mathrm{HDO}\left({ }^{1} \mathrm{H}^{2} \mathrm{HO}\right)$

$$
\text { or } \mathrm{H}_{2}{ }^{18} \mathrm{O} \text {; }
$$

$\delta x_{l}$ is the $\mathrm{D}$ or ${ }^{18} \mathrm{O}$ value in liquid water, in permil; and

$\delta x_{v}$ is the expected $\mathrm{D}$ or ${ }^{18} \mathrm{O}$ value in water vapor in equilibrium with the liquid water, in permil.

Fractionation factors for $\mathrm{D}$ and ${ }^{18} \mathrm{O}$ depend on temperature. At the study site, temperature increases as a function of depth in the deeper unsaturated sediments (Andraski and Prudic, 1997) and fluctuates seasonally in the upper $12 \mathrm{~m}$ (Fischer, 1992). A linear temperature gradient was assumed on the basis of temperatures measured in test hole UZB- 1 at depths of $14.9,34.1$, and $47.9 \mathrm{~m}$, and from the temperature of the ground water at $110 \mathrm{~m}$ when UZB-2 was drilled. The resulting temperature to depth relation $\left(\mathrm{r}^{2}=0.999\right)$ is:

$$
T=21.5+0.043 z,
$$

where $T$ is temperature in unsaturated sediments, in degrees Celsius; and

$z$ is depth below land surface, in meters.

Over the depth range of core samples (about 2.7 to $85 \mathrm{~m}$ ), temperatures predicted from this relation range from $21.6^{\circ}$ to $25.2^{\circ} \mathrm{C}$. Over this temperature range, the fractionation factor for $\mathrm{D}$ varies from 1.083 to 1.079 and that for ${ }^{18} \mathrm{O}$ varies from 1.010 to 1.009 (Friedman and O'Neil, 1977). These fractionation factors are for pure water; that is, the effects of solutes in the water are neglected.
Unlike the stable isotopes of water vapor and liquid water, which appear to be in equilibrium, tritium concentrations in core water are consistently lower than those of water vapor from UZB-2 (fig. 6). At equilibrium, water vapor in the unsaturated sediments should have a lower tritium concentration than liquid water because of fractionation. The expected tritium concentration in water vapor (dotted line in fig. 6) was calculated from (Ferronsky and Polyakov, 1982):

$$
C_{v}=\frac{C_{l}}{\alpha_{H T O}},
$$

where $C_{v}$ is the tritium concentration in water vapor in equilibrium with liquid water, in tritium units;

$C_{l}$ is the tritium concentration in liquid water, in tritium units; and

$\alpha_{H T O}$ is the fractionation factor for tritiated water.

The fractionation factor, for tritium, between liquid water and water vapor varies from 1.108 to 1.103 over the assumed temperature range corresponding to the depths at which core samples were collected (Ferronsky and Polyakov, 1982).

\section{POSSIBLE EXPLANATIONS FOR OBSERVED TRITIUM DISTRIBUTIONS}

Different sampling times could explain all or some of the observed difference in tritium concentration between the core samples and water vapor. Tritium concentration in water vapor from UZB-2 increased from April 1994 to May 1996 at all sampled ports, as shown in figure 6. Figure 9 shows histories of tritium concentrations in water vapor from eight of the UZB-2 air ports between the depths of 5.5 and $94.2 \mathrm{~m}$. Values for water vapor in November 1992 and September 1993 were calculated from equation 4, assuming isotopic equilibrium between liquid water and water vapor. Values for depths corresponding to air ports were linearly interpolated from values of nearest core samples, assuming that the tritium concentrations in core samples collected from UZB-1 ( 6 m southwest of UZB-2) represent concentrations in UZB-2 at the same depths. The tritium concentration at $94.2 \mathrm{~m}$ was assumed to be below detection because tritium concentrations in core water at $85.2 \mathrm{~m}$ and in UZB-2 ground water at $110 \mathrm{~m}$ were below detection. 


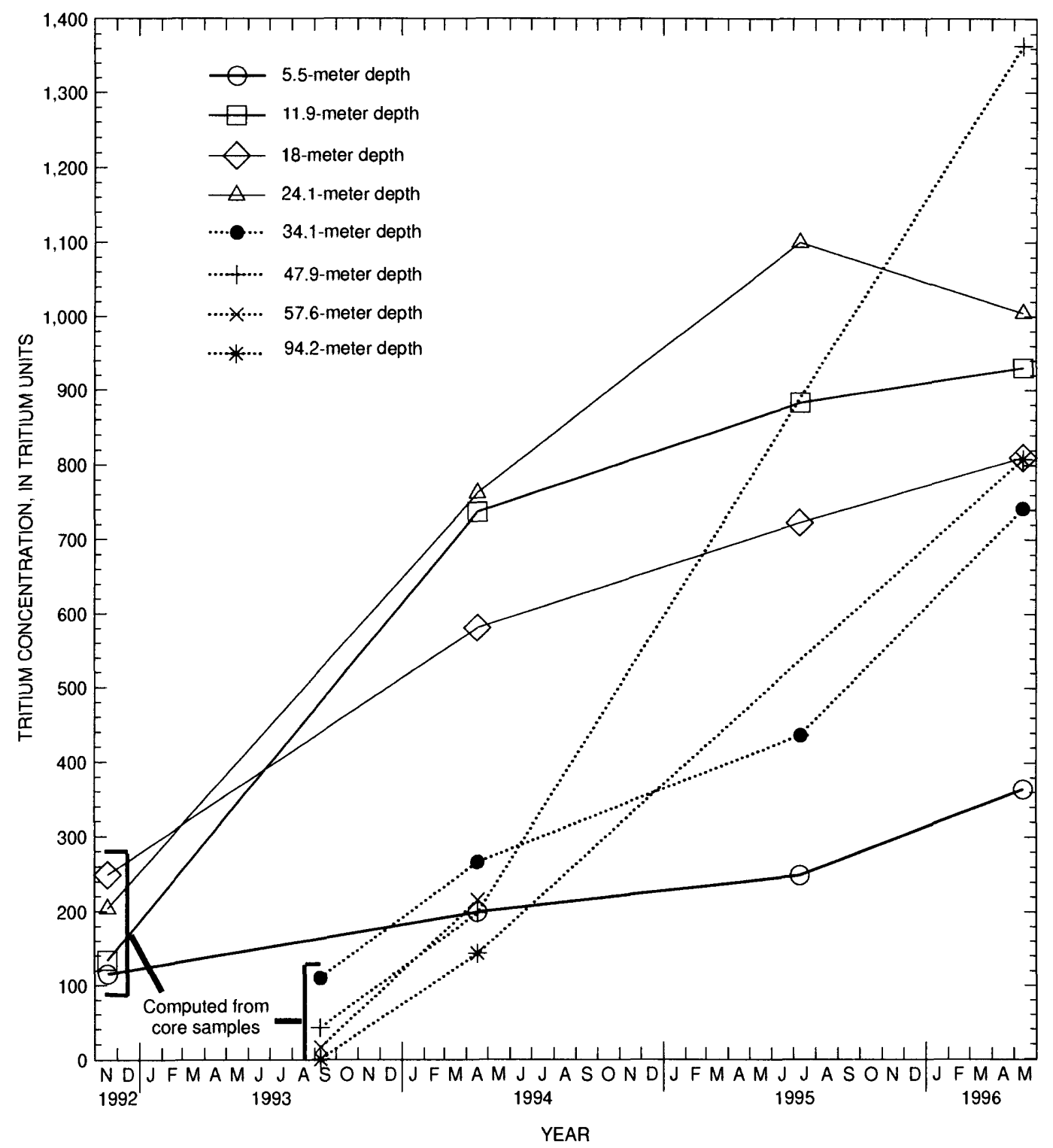

Figure 9. Concentrations of tritium in water vapor sampled from eight UZB-2 air ports in April 1994, July 1995, and May 1996, and concentrations in water vapor in November 1992 and September 1993, computed on the basis of water extracted from core samples. Test hole UZB-2 is near low-level radioactive-waste burial site south of Beatty, Nev.

The difference in tritium concentration (that is, the apparent disequilibrium) between core water and subsequently sampled vapor thus could be due to generally increasing tritium concentrations throughout the profile (fig. 9). The appearance of relatively high tritium concentrations that are unaccompanied by corresponding changes in stable isotopes probably reflects the introduction of water having a much greater contrast in tritium than in the stable isotopes.

The highest tritium concentrations, by far, were observed at the shallowest observation depths (that is, less than or equal to $2 \mathrm{~m}$ in the shallow probes).
The shallow probes were driven into a gravel layer that is present throughout the area. Moisture content in the gravel is about 0.02 gram of water per gram of soil (Fischer, 1992, p. 24). Lateral migration of tritium through the unsaturated sediments from the burial area is the most likely explanation of the tritium concentrations measured at UZB-2 (Striegl and others, 1996). As pointed out by Striegl and others (1996), however, migration of tritiated water is problematic. If water is in isotopic equilibrium with respect to tritium, and if the source of tritiated water is at least $100 \mathrm{~m}$ away, then the distribution of tritium at UZB-2 (including the shallow 
probe sample) cannot be explained by vapor transport alone (Striegl and others, 1996). Advective transport of tritium by liquid-water movement from the burial area should produce an increase in the water content at intervening points. Water content at the $30-\mathrm{m}$ deep shaft facility (fig. $1 B$ ) has not changed measurably below a depth of $1 \mathrm{~m}$ since 1987 (Andraski and Prudic, 1997). An alternate mechanism for moving tritium from the buried wastes involves diffusive transport by hydrogen gas or other hydrogen-containing gas that can move with little retardation before oxidizing to water (Jalbert and Murphy, 1988).

The possibility that the observed increase in tritium concentration in water vapor might result from one or more artifacts of drilling and sampling is considered next. During drilling, about $25 \mathrm{~m}^{3}$ of air per second at $2.4 \mathrm{MPa}$ was forced down the inside of the drill stem. Although much of this air returned to the surface through the annular space between the casing and the drill stem, some penetrated the sediments at the air hammer. Except for the core from 72.5- to 73.1-m depth, samples selected for water extraction were the deepest $15-\mathrm{cm}$ section of each $0.6-\mathrm{m}$ core and as such were the furthest removed from the point of air introduction during coring and drilling. Even so, the airfilled pore space may have been completely replaced by atmospheric air during sample collection. Furthermore, the advancing drill bit would act as a moving point source of high air pressure. Movement of gas away from this moving point source could smear any pre-existing peaks (that is, reduce tritium gradients with depth) and dilute any high tritium gas near the borehole, at least temporarily. Finally, the energetic hammering required to advance holes in the gravelly sediments may have increased the permeability of the sediments immediately adjacent to the borehole. All of these processes could result in atmospheric air entering pore spaces during drilling and core sampling.

Although some air undoubtedly penetrated the cored sediments during collection, the mass of water in the air-filled pore space is tens of thousands times lower than the mass of liquid water in the core samples, even for the relatively dry conditions at the site. Introduced air would be insufficient to significantly affect the tritium concentration in core samples, especially during a brief exposure. Present-day atmospheric air has a tritium concentration of about 15 TU. If introduced air had significant effects, then the core sample at $85 \mathrm{~m}$ would not have had the low tritium concentration observed, which was close to detection (table 2).
The small volumes of gas removed while sampling water vapor were insufficient to cause migration of tritiated vapor from the burial area to UZB-2. At most 4,300 L of gas was pumped from each port during a single sampling period (April 1994, June 1995, and May 1996). Assuming an air-filled porosity of 0.2 (volumetric water content of $0.1 \mathrm{~m}^{3} / \mathrm{m}^{3}$ ), the volume of unsaturated sediments containing the needed volume of gas was $22 \mathrm{~m}^{3}$. If the gas flowed to the air port equally from all directions (spherically), then the distance gas was pumped from the sediments extended 1.7 $\mathrm{m}$ from the air port. If gas flowed horizontally and was limited to the vertical thickness of the gravel pack around each air port $(0.6 \mathrm{~m})$, then the horizontal distance that gas was pumped from the sediments extended about $4 \mathrm{~m}$ from the air port. Both distances are considerably less than the $101 \mathrm{~m}$ to the security fence and the $220 \mathrm{~m}$ to the nearest burial trench inside the burial area. Moreover, the elevated tritium concentrations found in core water, given that cores were collected prior to pumping, indicates the introduction of tritium at UZB-2 before drilling.

Large changes in tritium concentrations between adjacent core samples and adjacent water-vapor samples in the upper $12 \mathrm{~m}$ (fig. 6) suggest that pumping gas from air ports did not introduce tritiated water vapor from the shallow gravel layer at $2 \mathrm{~m}$ down a hypothesized high-permeability zone created while installing UZB-2. However, residual effects of injected air could be significant. Pumping of UZB-2 air ports may be removing diluted air, and explain at least some of the continued increase in tritium concentration in water vapor.

If the observed increase of tritium in water vapor is caused by artifacts of drilling and sampling, then the observed tritium concentration in water vapor is not in equilibrium with the concentration in liquid water (fig. 6). Some liquid water may not be readily available for isotopic exchange because the water is adsorbed in tiny pores such as interlaminar spaces in clays. The ordered structure of water caused by hydrogen bonding extends outward from mineral surfaces into the pore space (Dragun, 1988). Exchange of tritiated water requires displacement of nontritiated water molecules, which may be slow because hydrogen bonds among water molecules must be broken for exchange to occur (John Matuszek, New York State Department of Health, written commun., 1996).

Loss of tritium to the atmosphere while core samples were stored prior to water extraction was probably minimal for most core samples. Evaporative loss of 
water from the core samples during storage would result in an increase, not a decrease, in the concentration of tritium in the remaining water. The relative humidity of the storage cabinet was sufficiently low that if the protective covering on the core samples was compromised, evaporation would have occurred. If evaporation during storage had been significant, then the predicted stable isotopic composition of water vapor from cores would not agree with the measured water vapor from UZB-2. As discussed on page 11, however, there probably was some evaporation from the core sample at $72.5 \mathrm{~m}$.

\section{SUMMARY AND CONCLUSIONS}

Pore water was extracted in March 1996 from core samples that were collected November 1992 and September 1993 from test holes UZB-1 and UZB-2. The test holes were drilled about $100 \mathrm{~m}$ south of the southwest corner of a fence enclosing a commercial burial area for low-level radioactive waste south of Beatty, Nev. Test hole UZB-2 was instrumented with 10 stainless-steel screens to collect gas samples from specific intervals in the unsaturated zone. The test holes are part of a study to determine the factors affecting water and gas movement through unsaturated sediments at the desert site.

Pore water was extracted from the archived core samples because water vapor collected from test hole UZB-2 in April 1994 and July 1995 had greater than expected tritium concentrations. An apparatus was constructed that extracted water directly from samples in their original brass core liners by cryodistillation. The extracted core water was analyzed for tritium, D, and ${ }^{18} \mathrm{O}$, and compared to water vapor collected from the air ports.

The $\delta \mathrm{D}$ and $\delta^{18} \mathrm{O}$ values in core water become more negative (more depleted, or lighter) with depth and are nearly uniform below a depth of $30 \mathrm{~m}$. Core water at depths less than $12 \mathrm{~m}$ is more evaporated than core water at greater depths. The stable isotopes plot on an evaporation trend. The source of the partly evaporated water could be either ground water or past precipitation having the same average isotopic composition as ground water, but not modern precipitation, on the basis of 18 months of record.

Profiles of $\delta \mathrm{D}$ and $\delta^{18} \mathrm{O}$ values in water vapor are similar to that in the core water. When fractionation between liquid and vapor is considered, the measured values of water vapor are in equilibrium with that of core water. Values of $\delta \mathrm{D}$ and $\delta^{18} \mathrm{O}$ for water vapor from the shallow probe $(1.7 \mathrm{~m})$ at UZB-2 indicate that water vapor is heavier (originates from water that is more evaporated) than water vapor sampled from greater depths. Water vapor from two other shallow probes, at depths of 1.8 and $2.0 \mathrm{~m}$, has a similar isotopic composition to the shallow probe at UZB-2. The data are consistent with the hypothesis of evaporative discharge of ground water at the land surface.

Tritium concentration in water from core samples collected at depths less than $50 \mathrm{~m}$ was higher than that of atmospheric air that was injected during drilling. Thus, the relatively high (less than 500 TU but more than $15 \mathrm{TU}$ ) tritium concentrations in water from core samples must have preceded drilling. The concentration in water from the deepest core sample $(85 \mathrm{~m})$ was below detection. Ground water from UZB-2 sampled at the time it was drilled also was below detection. Therefore, tritium at UZB-2 is coming laterally through the unsaturated zone as opposed to coming from ground water.

The shape of the tritium profile from core water is similar to that from water vapor collected in April 1994, except that tritium concentrations are consistently lower in core water than in water vapor. Tritium concentrations in vapor from UZB-2 increased from April 1994 to May 1996. Concentrations of tritium in water vapor that is assumed to be in equilibrium with liquid water from the 1992 and 1993 core samples form consistent temporal trends with measured concentrations in vapor samples collected in April 1994, July 1995, and May 1996. Increasing concentrations of tritium may explain the difference between the earlier core samples and the later vapor samples. The highest concentrations of tritium observed (up to 29,000 TU) were in water vapor from the shallow probes. These were installed in a laterally extensive gravel layer 1-2 $\mathrm{m}$ deep. Both core water and water vapor at UZB- 1 and UZB-2 indicate a bimodal distribution of tritium with the highest concentrations at shallow depths.

\section{REFERENCES CITED}

Andraski, B.J., and Prudic, D.E., 1997, Soil, plant, and structural considerations for surface barriers in arid environments-Application of results from studies in the Mojave Desert near Beatty, Nevada in Barrier Technologies for Environmental Management, Summary of a Workshop: Washington, D.C., National Academy Press, p. D50-D60. 
Andraski, B.J., Prudic, D.E., and Nichols, W.D., 1995, Waste burial in arid environments-Application of information from a field laboratory in the Mojave Desert, southern Nevada: U.S. Geological Survey Fact Sheet FS179-95, $4 \mathrm{p}$.

Black, S.C., Glines, W.M., and Townsend, Y.E., eds., 1994, U.S. Department of Energy Nevada Operation Office annual site environmental report - 1993, volume II appendices: Las Vegas, Nev., Reynolds Electrical and Engineering Co., Inc., report DOE/NV/11432-123, v. II, $421 \mathrm{p}$.

Coplen, T.B., 1993, Uses of environmental isotopes, in Alley, W.M., ed., Regional ground- water quality: New York, Van Nostrand Reinhold, p. 227-254.

Coplen, T.B., Wildman, J.D., and Chen, J., 1991, Improvements in the gaseous hydrogen-water equilibration technique for hydrogen isotope ratio analysis: Analytical Chemistry, v. 63. p. 910-912.

Craig, Harmon, 1961, Isotopic variations in meteoric water: Science, v. 133, no. 3465, p. 1702-1703.

Dragun, James, 1988, The soil chemistry of hazardous materials: Silver Spring, Md., Hazardous Materials Control Research Institute, $458 \mathrm{p}$.

Epstein, S., and Mayeda, T., 1953, Variation of $\mathrm{O}^{18}$ content of waters from natural sources: Geochimica et Cosmochimica Acta, v. 4, no. 5, p. 213-224.

Evans, E.A., 1966, Tritium and its compounds: Princeton, N.J., Van Nostrand, 441 p.

Ferronsky, V.I., and Polyakov, V.A., 1982, Environmental isotopes in the hydrosphere: New York, John Wiley and Sons, $762 \mathrm{p}$.

Fischer, J.M., 1992, Sediment properties and water movement through shallow unsaturated alluvium at an arid site for disposal of low-level radioactive waste near Beatty, Nye County, Nevada: U.S. Geological Survey Water-Resources Investigations Report 92-4032, 48 p.

Friedman, Irving, and O'Neil, J.R., 1977, Compilation of stable isotope fractionation factors of geochemical interest (6th ed.): U.S. Geological Survey Professional Paper 440-KK, $12 \mathrm{p}$.

Fritz, P., and Fontes, J.Ch., eds., 1980, Handbook of environmental isotope geochemistry: New York, Elsevier, v. 1, $545 \mathrm{p}$.

Gonfiantini, R., 1978, Standards for stable isotope measurements in natural compounds: Nature, v. 271, p. 534536.

Gvirtzman, Haim, and Magaritz, Mordeckai, 1986, Investigation of water movement in the unsaturated zone under an irrigated area using environmental tritium: Water Resources Research, v. 22, no. 5, p. 635-642.

Halevy, E., 1964, The exchangeability of hydroxyl groups in kaolinite: Geochimica et Cosmochimica Acta, v. 28, p. 1139-1145.
Hammermeister, D.P., Blout, D.O., and McDaniel, J.C., 1985, Drilling and coring methods that minimize the disturbance of cuttings, core, and rock formation in the unsaturated zone, Yucca Mountain, Nevada: Conference on Characterization and Monitoring of the Vadose (Unsaturated) Zone, National Water Well Association, Denver, Colo., November 1984, Proceedings, p. 507541.

Jalbert, R.A., and Murphy, C.E., 1988, The Canadian experimental HT release of June 10, 1987, U.S. measurements: Los Alamos National Laboratory LA-11368-MS, UC-702, 27 p.

Kendall, Carol, and Coplen, T.B., 1985, Multisample conversion of water to hydrogen by zinc for stable isotope determination: Analytical Chemistry, v. 57, no. 7, p. 1437-1440.

Milne, W.K., Benson, L.V., and McKinley, P.W., 1987, Isotope content and temperature of precipitation in southern Nevada, August 1983-August 1986: U.S. Geological Survey Open-File Report 87-463, 32 p.

Nichols, W.D., 1987, Geohydrology of the unsaturated zone at the burial site for low-level radioactive waste near Beatty, Nye County, Nevada: U.S. Geological Survey Water-Supply Paper 2312, $57 \mathrm{p}$.

Prudic, D.E., 1994, Estimates of percolation rates and ages of water in unsaturated sediments at two Mojave Desert sites, California-Nevada: U.S. Geological Survey Water-Resources Investigations Report 94-4160, 19 p.

-1996 , Water-vapor movement through unsaturated alluvium in Amargosa Desert near Beatty, NevadaCurrent understanding and continuing studies, in Stevens, P.R., and Nicholson, T.J., eds., Conference on disposal of low-level radioactive waste, Reston, Va., May 1993: U.S. Geological Survey Water-Resources Investigations Report 95-4015, p. 157-165.

Prudic, D.E., and Striegl, R.G., 1995, Tritium and radioactive carbon $\left({ }^{14} \mathrm{C}\right)$ analyses of gas collected from unsaturated sediments next to a low-level radioactive-waste burial site south of Beatty, Nevada, April 1994 and July 1995: U.S. Geological Survey Open-File Report $95-$ $741,7 \mathrm{p}$.

Striegl, R.G., 1988, Distribution of gases in the unsaturated zone at a low-level radioactive-waste disposal site near Sheffield, Illinois: U.S. Geological Survey WaterResources Investigations Report 88-4025, 69 p.

Striegl, R.G., Prudic, D.E., Duval, J.S., Healy, R.W., Landa, E.R., Pollock, D.W., Thorstenson, D.C., and Weeks, E.P., 1996, Factors affecting tritium and ${ }^{14}$ Carbon distributions in the unsaturated zone near the low-level radioactive-waste burial site south of Beatty, Nevada: U.S. Geological Survey Open-File Report 96-110, 16 p. 
Thatcher, L.L., Janzer, V.J., and Edwards, K.W., 1977, Methods for the determination of radioactive substances in water and fluvial sediments: U.S. Geological Survey Techniques of Water-Resources Investigations, book 5 , chap. A5, 95 p.

Tyler, S.W., Chapman, J.B., Conrad, S.H., Hammermeister, D.P., Blout, D.O., Miller, J.J., Sully, M.J., and Ginanni, J.M., 1996, Soil-water flux in the southern Great Basin, United States: Temporal and spatial variations over the last 120,000 years: Water Resources Research, v. 32, no. 6, p. 1481-1499.

Yang, I.C., Rattray, G.W., and Yu, Pei, 1996, Interpretation of chemical and isotopic data from boreholes in the unsaturated zone at Yucca Mountain, Nevada: U.S. Geological Survey Water-Resources Investigations Report 96-4058, $58 \mathrm{p}$. 